\title{
Consumption of Chlorogenic Acids through Coffee and Health Implications
}

\author{
Adriana Farah * and Juliana de Paula Lima \\ Laboratório de Química e Bioatividade de Alimentos e Núcleo de Pesquisa em Café (NUPECAFÉ), \\ Instituto de Nutrição, Universidade Federal do Rio de Janeiro, Avenida Carlos Chagas Filho, 373, CCS, Bl. J, \\ Rio de Janeiro 21941-902, Brazil; julianadepaula.nutricao@gmail.com \\ * Correspondence: afarah@nutricao.ufrj.br; Tel.: +55-21-39386449
}

Received: 11 December 2018; Accepted: 15 January 2019; Published: 1 February 2019

\begin{abstract}
Chlorogenic acids (CGA) are the main antioxidant compounds in the Western diet, due to their high concentrations in coffee associated with the high consumption of the beverage. Until about 10 years ago, like many other phenolic compounds, CGA were thought to be poorly absorbed in the human digestive system. Along the years, large amounts of information on the absorption and metabolism of these compounds have been unveiled, and today, it is known that, on average, about one third of the consumed CGA from coffee is absorbed in the human gastrointestinal tract, although large inter-individual variation exists. Considering results from in vitro animal and human studies, it is possible to conclude that the antioxidant and anti-inflammatory effects of coffee CGA are responsible for, at least to a certain extent, the association between coffee consumption and lower incidence of various degenerative and non-degenerative diseases, in addition to higher longevity.
\end{abstract}

Keywords: chlorogenic acids; coffee beverages; consumption; health effects

\section{Introduction}

Chlorogenic acids (CGA), esters of trans-hydroxycinnamic acids and quinic acid (Figure 1), were discovered in 1837 [1]. They were first thought to be caffetannic acid [2], which was in fact a mixture of different acids. Later, CGA were found to be distinct from tannic acid, the latest only found in green coffee. In 1908, 5-caffeoylquinic acid (5-CQA) or chlorogenic acid, numbered according to the International Union of Pure and Applied Chemistry (IUPAC) recommendations [3], was first isolated from a cristaline potassium-caffeine chlorogenate complex by Gorter [2,4], who discovered that this compound was widely distributed in leaves and seeds of numerous plants [5] including phytotherapeutic ones. But at least until the early 1920s substances in coffee other than caffeine were considered to have no biological effects [6]. In 1950, the term isochlorogenic acid was given to another CGA fraction found in coffee which was purified by Corse et al. [7] in 1965 and came to be the mixture of the three main dicaffeoylquinic acids (diCQA) [8]. By the end of the 60s, the neochlorogenic and cryptochlorogenic acids, corresponding to 3-caffeylquinic (3-CQA) and 4-caffeoylquinic (4-CQA) acids, respectively, according to IUPAC [3] as well as the three main feruloylquinic acids (3-FQA, 4-FQA, and 5-FQA) had already been isolated and identified by Nuclear Magnetic Resonance (NMR) spectroscopy [8]. In the late 70s and early 80s, the use of liquid chromatography enabled the identification of nine major CGA and other minor compounds in the coffee matrix [8]. From the beginning of the 90s and on, a new field of research laid in the study of CGA antioxidant attributes and their physiological significance stimulated studies with decaffeinated coffee. Discovered and isolated in the 80s [9], quinic acid lactones or quinides formed by dehydration of the quinic acid moiety during roasting (Figure 2) also gained physiological importance in the 90s [10-14]. Currently, more than 300 major and 
minor CGA and related compounds such as dicaffeoylquinic acids (diCQA), diferuloylquinic acids, caffeoylferuloylquinic acids, dimethoxycinnamoylquinic acids, caffeoyldimethoxycinnamoylquinic acids, trimetoxycinnamoylcaffeoylquinic acids; feruloyldimethoxycinnamoylquinic acid, sinapoylquinic acids, sinapoylcaffeoylquinic acids, sinapoylferuloylquinic acids, and related compounds, in addition to a number of new minor $p$-coumaric acid-containing compounds have been described both in coffee [15-24] and in other plant materials [25,26], and a number of potential beneficial effects of CGA have been revealed in vitro and in animal studies, corroborating results of epidemiological studies. The aim of this review was to raise the awareness of coffee consumers and not consumers for the high intake of CGA through coffee and for their potential beneficial health effects on health.

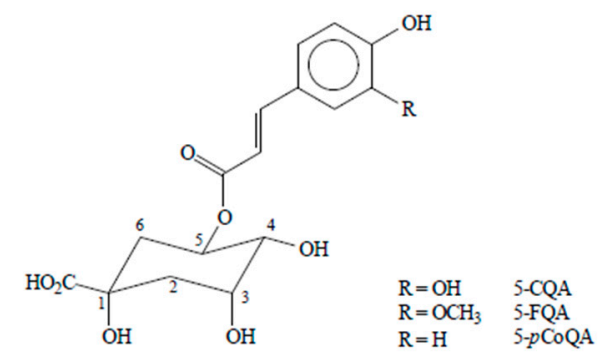

(a) Monoacyl-esters

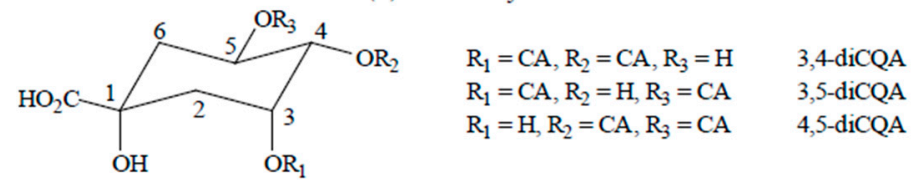

(b) Diacyl-esters

Figure 1. Major chlorogenic acids found in coffee. CQA: caffeoylquinic acids; FQA: feruloylquinic acids; $p$-CoQA: $p$-coumaroylquinic acids; diCQA: dicaffeoylquinic acids. When citing other authors, their numbering has been changed for consistency. Numbering follows the International Union of Pure and Applied Chemistry (IUPAC) numbering system [3], which has been recently discussed, in other reviews [23,24].<smiles>O=C(/C=C/c1ccc(O)c(O)c1)OC1CC(O)(C(=O)O)CC(O)C1O</smiles>

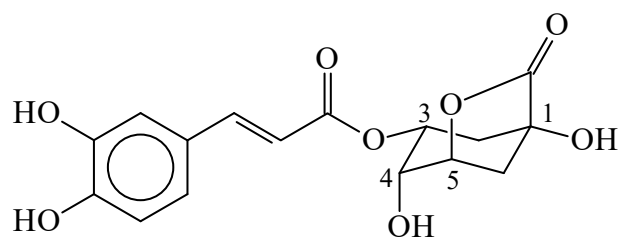

Figure 2. Formation of 1,5-quinolactone during coffee roasting, exemplified by 3-caffeoylquinide3CQL. Note: Although under IUPAC rules the numbering system [3] for the lactones is different from the acids, to avoid confusion, the authors used for lactones the same numbering of the carbon atoms as for the acid precursors.

\section{Chlorogenic Acids Levels in Coffee Beverages and Estimated Daily Consumption through Coffee}

Together with mate (Ilex paraguariensis) green coffee seed is the main known source of CGA in nature, especially in Coffea canephora, cultivars (Robusta and Conilon), in which contents commonly reach 7-8 g/100 g (dry matter- $\mathrm{dm}$ ), while in C. arabica cultivars 4-6 g/100 g (dm) are more common. However, coffee is mostly consumed after roasting and as CGA are thermolabile compounds, in addition to being isomerized, epimerized, and lactonized, a considerable amount can be lost by degradation during roasting, although part of hydroxycinammic acids can be incorporated into the melanoidins structures formed in Maillard reaction as roasting progresses. Reasonable ranges of contents reported for CGA in laboratory roasted seeds considering various roast degrees are $0.4-2.9 \mathrm{~g} / 100 \mathrm{~g}(\mathrm{dm})$ for C. arabica and $0.4-5.9 \mathrm{~g} / 100 \mathrm{~g}$ (dry basis) in C. canephora seeds [27]. The more coffee is roasted the lower is the content difference between species. In medium roasted coffees, 
reported CGA contents vary from about 1.7 to $3.5 \mathrm{~g} / 100 \mathrm{~g}(\mathrm{dm})$ for C. arabica and from 1.0 to $4.3 \mathrm{~g} / 100 \mathrm{~g}$ (dm) for C. canephora. Reported contents for commercial blends (including lactones) of various roast degrees vary from 0.2 to $3.1 \mathrm{~g} / 100 \mathrm{~g}(\mathrm{dm})$ in different countries [27].

In general, the levels of CGA (including their lactones) in coffee brews as reported in the literature may vary largely, from $26 \mathrm{mg} / 100 \mathrm{~mL}$ (including studies that only reported concentrations of the three main CQA isomers) [28,29] to extreme $1141 \mathrm{mg} / 100 \mathrm{~mL}$ (considering unusually concentrated espresso coffees) [30,31], but common values, including caffeoylquinic, feruloylquinic and dicaffeoylquinic compounds, and their main lactones (1,5-caffeoylquinides), range from 50-200 mg/100 mL [32,33]. Percent distribution of CGA compounds in coffee brew, in order of abundance is, on average: 5-CQA (41\%-48\%), 4-CQA ( $20 \%-25 \%)$, 3-CQA (17\%-20\%), 5-FQA (4\%-8\%), 4-FQA ( $2 \%-5 \%)$, 3-FQA ( $1 \%-4 \%)$, 3,4-diCQA $(1 \%-2.5 \%), 3,5$-diCQA $(1 \%-1,5 \%), 4,5(\sim 1 \%)$, others $(<1 \%)[33,34]$.

The first variable that leads to such large range of CGA values in coffee brew is the blend. It may contain different percentages of varied types of coffee seeds, including cultivars of C. arabica and C. canephora species, grown under different edaphoclimatic conditions, and in different degrees of maturation (the latter in the case of a lower quality blend), and processed by a variety of post-harvest methods. All these variables affect coffee chemical composition including CGA content [27]. There are also the roast degrees and roast profiles that will also affect CGA content. The roasted seeds can then be ground to different sizes and the proportion of powder to water classically used can also change dramatically between countries and cultures. For example, while in most European countries, in the USA and Canada the use of $\sim 7 \mathrm{~g}(1 / 4 \mathrm{oz})$ per $100 \mathrm{~mL}$ is common for filtered coffees, in Brazil $10 \mathrm{~g}$ or more are used. In Italy, the use of $20 \mathrm{~g}$ of ground roasted coffee is also not uncommon per $100 \mathrm{~mL}$. In espresso coffee, although traditionally $6-8 \mathrm{~g}$ is used for each $25 \mathrm{~mL}$ of water, an extreme proportion of $10 \mathrm{~g}$ for $25 \mathrm{~mL}$ water is nowadays often used by $3 \mathrm{rd}$ wave baristas $[35,36]$. Then, there are a variety of brewing methods where pressure, temperature, and contact time between the water and ground coffee may vary considerably. Despite all variations, domestic brewing can extract considerable amounts of CGA (40\%-95\%) from roasted coffee [33,37-39] with tendency for lower extraction of diCQA compared to CQA and FQA because of their lower solubility.

In general, considering the different existing brewing methods (Table 1), the values reported for major CGA (CQA, FQA, and diCQA), including the major lactones, in brews prepared at $6 \%-17.5 \%$, (weight/water volume) using light to dark ground roasted coffees vary as follows: from $\sim 25$ to $150 \mathrm{mg} / 100 \mathrm{~mL}$ in manually dripped (filtered) brews [33,34,40], from $\sim 35$ to $170 \mathrm{mg} / 100 \mathrm{~mL}$ in electric dripper (filtered) brews [33,34,41,42], from $\sim 40$ to $1000 \mathrm{mg} / 100 \mathrm{~mL}$ in espresso brews [30,32-34,41,42]; from $\sim 55$ to $150 \mathrm{mg} / 100 \mathrm{~mL}$ in Italian coffee brews prepared by moka pot [32-34,41,42]; from 40 to $280 \mathrm{mg} / 100 \mathrm{~mL}$ in French press brews [32,42,43]; about $110-200 \mathrm{mg} / 100 \mathrm{~mL}$ in Turkish coffee brews [29,34], from $~ 70$ to $230 \mathrm{mg} / 100 \mathrm{~mL}$ in boiled coffee brews [28,33,34,42]; and approximately 35 to $319 \mathrm{mg} / 100 \mathrm{~mL}$ in cold-dripped brews [32,34,43,44].

In espresso brews, CGA contents can be much higher than in brews prepared by dripping/filtered or other methods, first simply due to the use of higher proportion of ground coffee per water volume in general. Additionally, the espresso machine may extract CGA more efficiently due to the high pressure applied to the extraction process (commonly 9 bar). In addition to espresso, high concentrations of CGA can be found in brews made using a moka pot, mainly due to water evaporation and brew concentration associated with higher water pressure compared to dripping methods [45]. For cold brews, there are a number of methods in which temperature and infusion times vary considerably. In general, cold brews from short infusion periods and lower temperatures tend to yield lower CGA concentrations in the cup [34,43]. In the same way, higher temperatures up to $95^{\circ} \mathrm{C}$ tend to result in greater extraction of CGA $[37,38]$, but keeping coffee brews heated at elevated temperatures may reduce their content in the brew $[11,12]$.

The reported contents of CGA (including lactones) in solid soluble coffee vary largely in the literature, from 0.7 to $9.0 \mathrm{~g} / 100 \mathrm{~g}(\mathrm{dm})$ for roasted coffees [37,46-48]; from 10.2 to $21.1 \mathrm{~g} / 100 \mathrm{~g}(\mathrm{dm})$ for green (unroasted) coffees that are usually consumed in capsules [34,48], and from 4.6 to $6.7 \mathrm{~g} / 100 \mathrm{~g}$ 
in blends containing both roasted and unroasted coffees [34,45]. Values in dissolved coffee can be obtained considering that $4 \mathrm{~g}$ or less are used per $100 \mathrm{~mL}$ cup [49]. After dissolution in hot water, total CGA content should be similar to those in percolated extracts from ground roasted coffees, with potentially higher contents in freeze-dried compared to spray-dried coffees [34]. However, because in many countries soluble coffee is commonly prepared from blends containing high percentage of C. canephora seeds, after dissolution in water, such beverages often contain more CGA and lactones than those prepared from ground roasted coffee (with higher percentage of $C$. arabica seeds) and, in this case, daily consumption of CGA would increase through soluble coffee consumption [45]. Table 1 includes values from studies in which quantification of at least the three main coffee CGA (CQA) have been performed in brews. 
Table 1. Chlorogenic acids contents in coffee brews obtained by different extraction methods.

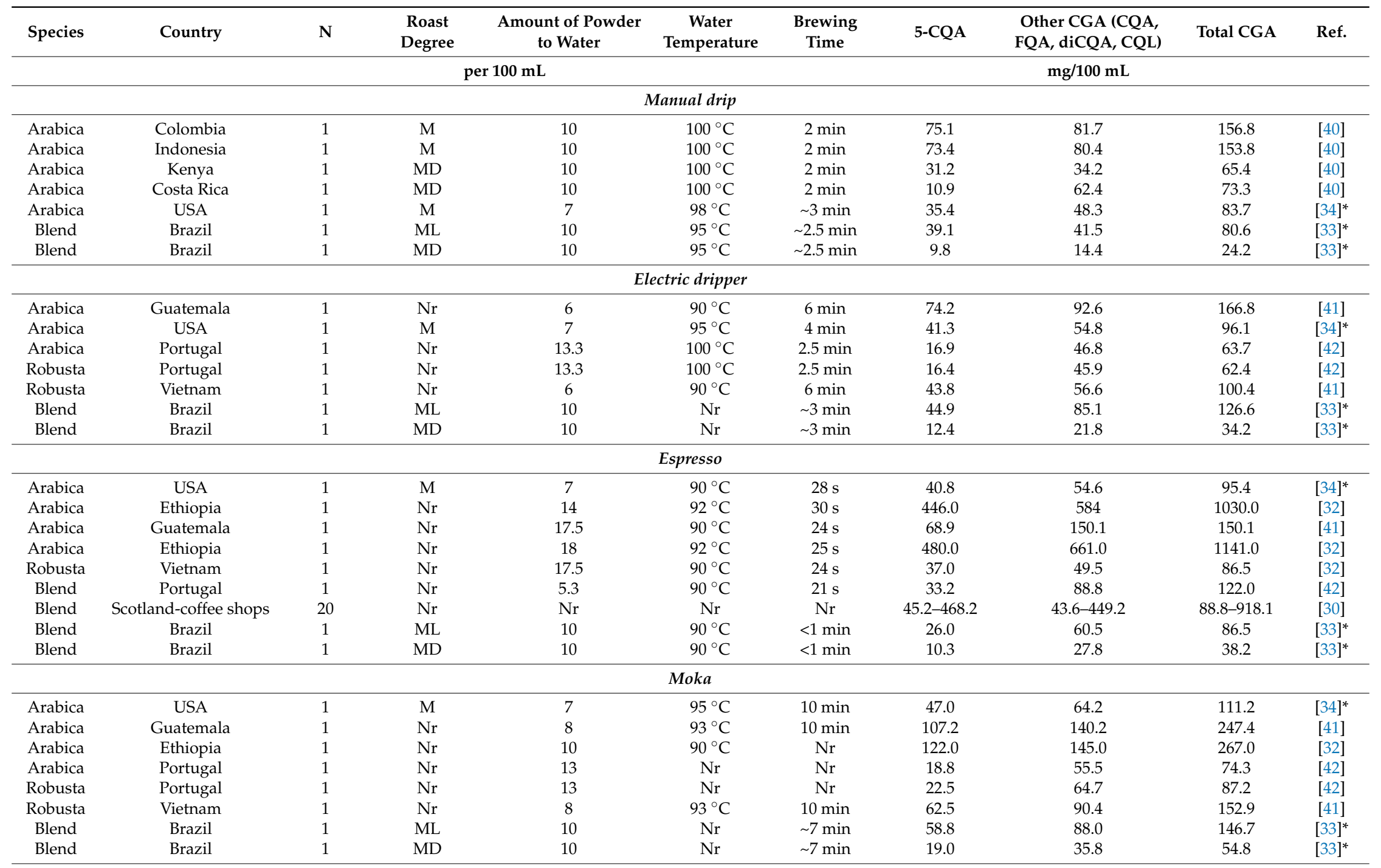


Table 1. Cont.

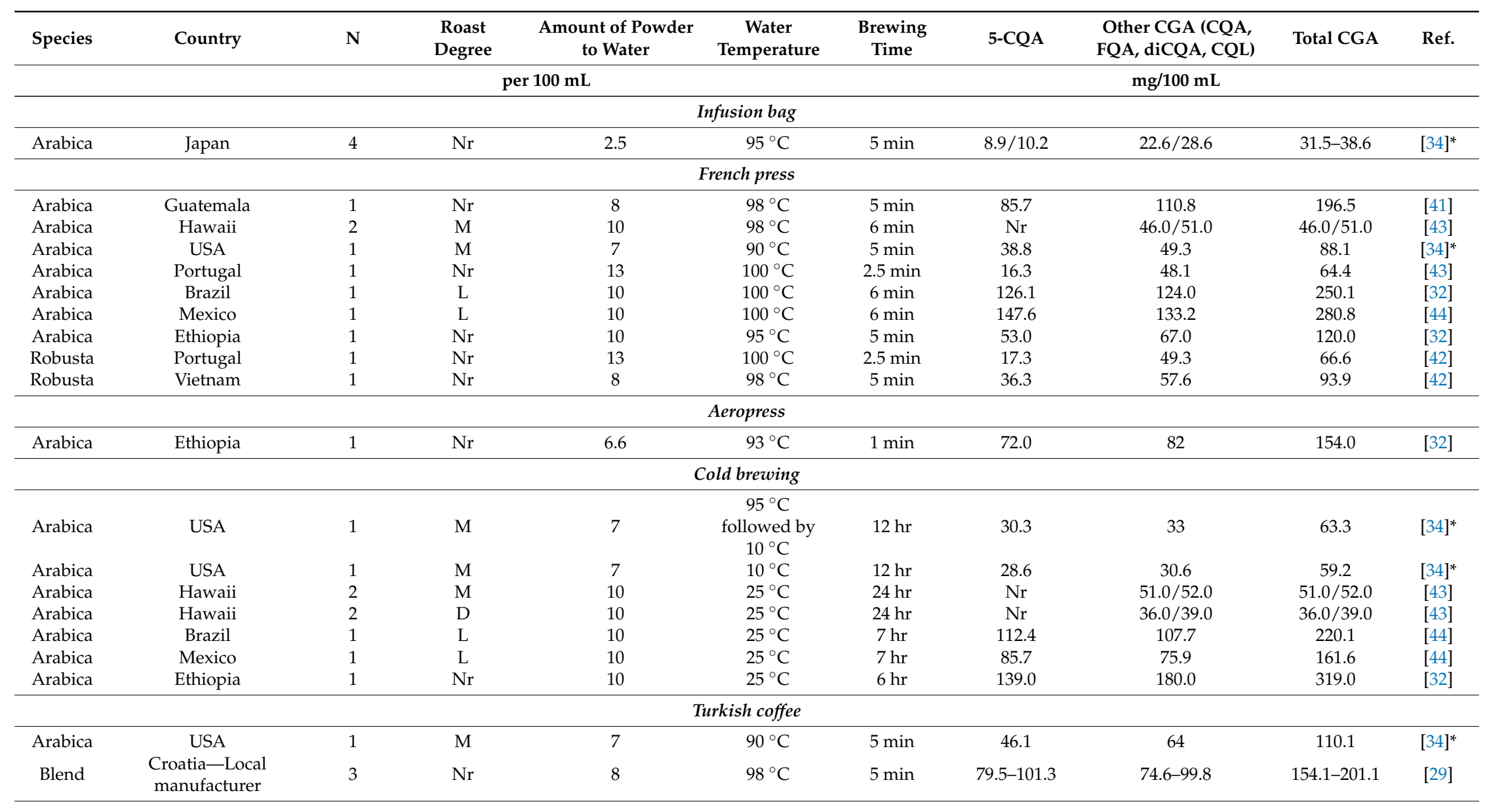


Table 1. Cont.

\begin{tabular}{|c|c|c|c|c|c|c|c|c|c|c|}
\hline Species & Country & $\mathbf{N}$ & $\begin{array}{l}\text { Roast } \\
\text { Degree }\end{array}$ & $\begin{array}{c}\text { Amount of Powder } \\
\text { to Water }\end{array}$ & $\begin{array}{c}\text { Water } \\
\text { Temperature }\end{array}$ & $\begin{array}{l}\text { Brewing } \\
\text { Time }\end{array}$ & $5-\mathrm{CQA}$ & $\begin{array}{l}\text { Other CGA (CQA, } \\
\text { FQA, diCQA, CQL) }\end{array}$ & Total CGA & Ref. \\
\hline \multicolumn{8}{|c|}{ per $100 \mathrm{~mL}$} & \multicolumn{3}{|l|}{$\mathrm{mg} / 100 \mathrm{~mL}$} \\
\hline \multicolumn{11}{|c|}{ Boiled coffee } \\
\hline Arabica & USA & 1 & M & 7 & $95{ }^{\circ} \mathrm{C}$ & $5 \min$ & 45.2 & 59.7 & 104.9 & {$[34]^{*}$} \\
\hline Arabica & Brazil & 1 & $\mathrm{~L}$ & 10 & $100^{\circ} \mathrm{C}$ & $\mathrm{Nr}$ & 126.5 & 169.1 & 295.6 & [28] \\
\hline Arabica & Brazil & 1 & M & 10 & $100^{\circ} \mathrm{C}$ & $\mathrm{Nr}$ & 30.7 & 51.2 & 81.9 & [28] \\
\hline Arabica & Brazil & 1 & D & 10 & $100^{\circ} \mathrm{C}$ & $\mathrm{Nr}$ & 8.7 & 17.4 & 26.1 & [28] \\
\hline Arabica & Portugal & 1 & $\mathrm{Nr}$ & 13.3 & $100^{\circ} \mathrm{C}$ & $2 \min$ & 19.4 & 54.9 & 74.3 & [42] \\
\hline Blend & Brazil & 1 & ML & 10 & $100^{\circ} \mathrm{C}$ & $\sim 4$ min & 96.8 & 133.8 & 230.6 & {$[33]^{*}$} \\
\hline Blend & Brazil & 1 & MD & 10 & $100^{\circ} \mathrm{C}$ & $\sim 4 \mathrm{~min}$ & 23.6 & 47.5 & 71.13 & {$[33]^{*}$} \\
\hline \multicolumn{11}{|c|}{ Soluble or instant coffee beverage } \\
\hline $\mathrm{Nr}$ & Portugal & 3 & $\mathrm{Nr}$ & 1.3 & $100^{\circ} \mathrm{C}$ & - & $6.0-6.8$ & $11.0-15.2$ & $17.0-22.0$ & [42] \\
\hline $\mathrm{Nr}$ & UK & 2 & $\mathrm{~L}$ & 0.9 & $100^{\circ} \mathrm{C}$ & - & $5.7 / 7.2$ & $9.0 / 10.8$ & $14.7 / 18.0$ & [50] \\
\hline $\mathrm{Nr}$ & UK & 2 & $\mathrm{M}$ & 0.9 & $100^{\circ} \mathrm{C}$ & - & $7.1 / 7.5$ & $10.3 / 11.7$ & $17.4 / 19.2$ & {$[50]$} \\
\hline $\mathrm{Nr}$ & UK & 1 & $\begin{array}{l}\text { Green and } \\
\text { roasted }\end{array}$ & 0.9 & $100^{\circ} \mathrm{C}$ & - & 21.5 & 22.5 & 44.0 & {$[50]$} \\
\hline \multicolumn{11}{|c|}{ Ready to drink cold coffee beverage } \\
\hline $\mathrm{Nr}$ & Japan & 4 & $\mathrm{Nr}$ & & - & - & $65.5-74.8$ & $141.0-169.0$ & $206.5-243.8$ & {$[34]^{*}$} \\
\hline
\end{tabular}

Note: N: number of samples; 5-CQA: 5-caffeoylquinic acid. Other CGA: 3-caffeoylquinic acid; 4-caffeoylquinic acid, 3-feruloylquinic acid; 4-feruloylquinic acid; 5-feruloylquinic acid, 3,4-dicaffeoylquinic acid; 3,5-dicaffeoylquinic acid; 4,5-dicaffeoylquinic acid, 3-caffeoylquinic-1,5-quinide; 4-caffeoylquinic-1,5-quinide. Roast degree: M: medium; ML: medium light; MD: medium dark, D: dark; L: light. Nr: not reported. *Quantification of nine major CGA compounds and two lactones; Blend: blend of C. arabica and C. canephora. 
In addition to all exposed possibilities of variations before or during beverage preparation, the serving size (a cup of coffee) reported in scientific publications vary from about $25 \mathrm{~mL}$ for an Italian espresso up to $600 \mathrm{~mL}(20 \mathrm{oz})$ for a filtered brew in the US. The standard American cup, however, is often mentioned as being equivalent to about $237-250 \mathrm{~mL}$ ( 8 fluid oz) [36]. The European traditional cup has been defined in different studies including that of Floegel et al. [51] as containing $150 \mathrm{~mL}$. Finally, the different analytical methods may cause discrepancy in the reported compositional results, especially the least sensitive and specific methods, along with the fact that many reports only consider 5-CQA or the three main CQA isomers. Thus, instead of standard values to represent the chemical composition of a cup of coffee, including CGA content, a range of values seems to be more reasonable. Despite the large increase in consumption of espresso and other concentrated coffees around the world in the last few years, manual or electric dripping with paper or nylon filters are still the most used coffee preparation methods worldwide, including in the US, Canada, Brazil, Central America, and Nordic countries such as Finland, Sweden, Norway, and Denmark. Having said that, based on the value of $100 \mathrm{mg}$ CGA $/ 100 \mathrm{~mL}$ as the average of commonly reported contents in filtered coffee (prepared at 6-13.3\%) [33,34,40-42] (Table 1), the amounts of ingested CGA per serving of 25 to $600 \mathrm{~mL}$ can be estimated in approximately 25 to $600 \mathrm{mg}$. However, it is also possible to hypothesize that in the case of regular coffees, caffeine helps to regulate the amount of coffee consumed, i.e., strong (concentrated) coffees are commonly used for small servings and week coffees used for large servings.

About the daily CGA intake through coffee, because of the high coffee consumption, in many regions of the world this beverage is the main dietary source of CGA and antioxidants in general [52]. Among exceptions are countries or regions where mate tea is heavily consumed, like the southern regions of Brazil, Argentina, Uruguay, and Paraguay, or places where Camellia sinensis tea is mostly consumed, like in the UK and some Asian countries. Exceptions also include the case of coffee abstainers from all over the world [34]. Going from one extreme to another, Nordic countries have the highest daily coffee per capita consumption according to the International Coffee Organization (ICO) [53], and therefore probably the highest CGA consumption through coffee, while consumption in Asian countries, especially in Japan, is the lowest [53], with weak brews (about 2.5\%) resembling tea infusions. However, it should be noted that coffee consumption in China and Japan is increasing [53] and so is CGA consumption.

Considering the consumption of one to three cups of filtered coffee per day in modest coffee drinkers, (being the latest the amount recommended by several epidemiological studies) [54-56] and considering the average amount of $100 \mathrm{mg}$ CGA per $100 \mathrm{~mL}$ serving estimated above for filtered coffees, modest coffee drinkers might consume 100-300 mg CGA/day. Heavy consumers of filtered coffee, considering six $100 \mathrm{~mL}$ cups a day, therefore, might reach $600 \mathrm{mg}$ CGA/day. It is important to note that manually dripped or filtered coffees used for estimates contain the lowest amount of CGA among all methods, and therefore the consumption of larger servings than those used for calculations or even coffees extracted by other methods might considerably increase CGA daily intake. Nevertheless, as aforementioned, in the case of regular coffees, caffeine should help regulate the amount of coffee consumed per serving, while for decaffeinated coffee (about $12 \%$ of world coffee consumption) [57], CGA consumption can be higher.

Considering a few reports on the estimated per capita consumption of coffee brew in different countries, using the same rational as above we can estimate CGA consumption as $120 \mathrm{mg} /$ day for Spain [58], $215 \mathrm{mg} /$ day for Brazil [59], $237 \mathrm{mg} /$ day for Poland [60], $368 \mathrm{mg} /$ day for Iceland [61], $480 \mathrm{mg}$ /day for Norway [62], and $594 \mathrm{mg} /$ day for Finland [63].

\section{Bioavailability of Chlorogenic Acids and Lactones and Interaction with Other Food Components}

Studies on the metabolism and bioavailability of trans-hydroxycinnamic acids (initially limited to caffeic acid) and CGA started in the 50s, in the same period when the first isomers were discriminated [64]. Although urinary metabolites had already been identified since at least 1957 [65], 
until the last decade animal and human studies failed to detect intact CGA in plasma or serum after 5-CQA or coffee intake. In most studies, after 5-CQA or coffee intake, only small amounts of caffeic acid, a hydrolysis product of both CQA and diCQA, had been identified and quantified in murine or human plasma and urine. Therefore, it was generally concluded that less than $1 \%$ of CGA ingested was absorbed in animals and humans [66-68] and that almost the whole ingested amount was degraded during digestion, metabolized by the intestinal microflora, and/or excreted with feces [45]. In later studies, considerable amounts of 5-CQA in addition to two CQA, three diCQA, and two FQA compounds were identified in human plasma after consumption of roasted and green coffee extracts $[69,70]$. Other human studies followed, with improved analytical methodologies and use of synthetic metabolites standards, confirming the absorption and partial bioavailability of CGA, identifying new compounds and specifying forms of conjugation [45,71-75]. Considering human studies, maximum plasma concentration $\left(C_{\max }\right)$ of CGA and metabolites vary with dose, individual, and with analytical methodology applied in the studies, ranging from $\mathrm{nM}$ to low $\mu \mathrm{M}$ levels [45,69-75]. Today, a large amount of knowledge about CGA metabolism has been accumulated, despite the controversies about results involving the distribution of CGA subclasses (diCQA for example) and individual isomers in human fluids, most probably due to analytical circumstances involving enzyme treatment, acyl-migration, hydrolysis or degradation $[34,45,76]$. It has been estimated that on average, a third of the amount of CGA consumed is absorbed throughout the digestive tract, with a very large variability among individuals [34,45]. Absorption initiates early in the stomach but occurs mostly in the intestine by passive diffusion, and also with probable involvement of monocarboxylic acid transporter (MCT) [77-80] and perhaps of bilitranslocase (an anthocyanin transporter) [78]. Partial intestinal hydrolysis, predominant phase two metabolism (mostly involving sulfation and glucoronidation) and entero-hepatic circulation have been reported [69-75]. The unabsorbed portion of CGA, as with other polyphenols, is extensively hydrolyzed by gut bacteria, serving as potential prebiotic for beneficial bacteria [81-83]. These colonic metabolites can be absorbed and excreted in urine [69-71]. More studies are needed on the bioavailability of lactones, but partial absorption $[72,84,85]$ and partial degradation [71] of the main lactones have been reported in human and in vitro studies (for detailed information on in vitro, animal and human studies involving CGA and lactones, including pharmacokinetics, liver metabolism, etc., see References [34,45]).

Regarding possible CGA interaction with food components, the interaction between polyphenols and different dietary components has been extensively reported [86]. An important interaction occurs with proteins, especially casein and albumin. When consumed simultaneously with milk, 5-CQA, and hydroxycinnamic acids may interact with whey proteins such as $\beta$-lactoglobulin and with casein [87]. These complexes may not be susceptible to proteolysis by gastrointestinal enzymes such as trypsin, chymotrypsin, pepsin, and pancreatin impeding the release of phenolic compounds from the protein complex, and consequently, their absorption $[87,88]$. This event is not exclusive of coffee polyphenols; it has also been observed in various human studies involving tea [89] and cocoa polyphenols [90].

Confirming such in vitro findings, the urinary recovery of CGA and metabolites was evaluated after simultaneous consumption of water, instant coffee dissolved in water or in whole milk. The amount of CGA and metabolites recovered $24 \mathrm{~h}$ in urine after consumption of the mixture of milk and instant coffee (on average, $40 \%$ of the amount consumed) was consistently lower in all subjects compared to plain coffee (average of $68 \%$ ), indicating that adding coffee to milk quantitatively altered the absorption and/or the metabolism of CGA from coffee [91]. On the other hand, in another study [92], the addition of $10 \%$ whole milk or a pre-mixed non-dairy (fat rich) creamer with sugar to coffee did not increase or decrease CGA area under the curve in plasma, in despite of a delay in CGA appearance observed in the creamer test. The use of low amount of milk may have spared CGA's bioavailability in the first treatment. The second treatment contained more than one variable, which makes difficult to discuss. In contrast with the later study, a more recent in vitro study investigating the bioacessibility of coffee CGA [93] also reported that the addition of milk to coffee decreased CGA bioacessibility and that casein bound 5-CQA with high affinity. Different percentages of different 
bovine milk types (whole, semi skimmed, and skimmed) were tested and the presence of fat (50\% whole milk, $50 \%$ semi skimmed or $25 \%$ whole milk) strongly increased the bioacessibility of CGA.

A more recent study evaluated whether the simultaneous consumption of coffee and solid foods affected the absorption and bioavailability of CGA determined by the area under the curve of plasmatic CGA and metabolites' concentration [94]. Subjects consumed plain instant coffee, or coffee with either a high-carbohydrate meal (bread rolls and honey) or a high-fat meal (bread roll and peanut butter) containing the same amount of CGA ( $3.1 \mathrm{mg}$ CGA $/ \mathrm{kg}$ body weight). The authors observed significantly lower CGA bioavailability after consumption of a high-fat meal (which in fact also contained carbohydrate) compared to pure instant coffee. The high carbohydrate meal did not change CGA bioavailability compared to plain coffee but produced differences in the kinetic of release. The consumption of both meals with coffee delayed the appearance of colonic metabolites in urine. The effect of fat and sugar on CGA-protein interaction or in CGA absorption is still not clear and deserves further investigation.

Based on the urinary excretion of CGA and primary metabolites after coffee and a soy-coffee beverage consumption by humans [95], soy protein and/or other substances present in soymilk seem to also bind CGA (although to a lower extent compared to cow's milk), decreasing their absorption in the upper digestive tract, which corroborates in vitro results on interactions between CGA and soy protein [95-97].

Regarding the effect of coffee matrix variation, no difference has been observed in the $24 \mathrm{~h}$ human urinary recoveries of CGA and metabolites after the beverage consumption of green and roasted coffee extracts [98] and of green coffee and green mate extracts [99]. More studies on matrix effect are needed comparing the bioavailability of CGA from different food sources.

The interaction between polyphenols and different dietary components decreasing the bioavailability of the later has also been extensively reported [86]. Polyphenols can form complexes with metal cations through their carboxylic and hydroxylic groups, and thus interfere with the intestinal absorption of minerals. Numerous experiments in both humans and animals have shown that polyphenols strongly inhibit iron absorption [100]. The study of Gutnisky et al. [101] also reported an intense inhibitory effect of CGA from mate (Ilex paraguarensis) in the absorption of non-heme iron in rats. Such inhibitory effect has also been observed in coffee and attributed to GCA [102]. This finding is supported by the report on formation of a CGA chelate with iron which decreased induced lipid peroxidation in bovine liver microsomes [103].

\section{Effects of Chlorogenic Acids on Human Body and Health}

Along the past few years, a number of epidemiological studies have associated moderate coffee consumption, independently of caffeine, with the reduction in the relative risk of development of chronic degenerative diseases and death [54-56,104-108]. The beneficial effects of coffee can be attributed to the joint action of many bioactive compounds [109]. It is likely that most contributions to decreased risk of certain diseases are caused by synergistic or additive effects of the various compounds present in coffee [35]. However, in vitro and animal studies have linked certain compounds to specific mechanisms. In the case of CGA, most contribution to coffee's health effects are related to their antioxidant and anti-inflammatory activities [110-113] which include mechanisms involving signal transduction [114,115].

Because only a few CGA compounds are commercially available or synthesized in laboratories, studies on the biological properties of FQA, $p$-CoQA, CFQA, and minor CGA compounds are missing. Most biological activities reported for CGA are related to CQA compounds, especially 5-CQA. There are also some studies investigating the effects of synthesized CQL and diCQA, the latest being also present in considerable amounts in some types of propolis and other medicinal plant material. The CGA contribution to the preventive or healing effect of coffee will be briefly presented below. 


\section{Antioxidant Activity}

Coffee is the main source of antioxidant compounds in the diet of many populations [35,52] owing mainly to the high concentration of CGA and lactones in the brew associated with its high consumption. The high contribution of coffee and CGA to the dietary intake of antioxidative compounds is described in several reports from different countries. Based on the association of their official food consumption database or other types of surveys with the in vitro antioxidant capacity of foods, coffee was found to be the main percent contributor to total dietary antioxidant capacity, i.e., Brazil (66\%); Norway (64\%); Italy (38\% for women and $27 \%$ for men); Spain ( $45 \%$ ); Japan (56\%), and Czech Republic ( $54.6 \%$ for women and $43.1 \%$ for men) [35,52].

Oxidative stress is related to several degenerative diseases, cancer development, aging, and death $[116,117]$. Chemical-based assays, cell-based assays, and animal models have been established to investigate the antioxidant activity of CGA [111]. CGA are known to have similar antioxidant activity to ascorbic acid [118]. They are able to quelate transition metals such as $\mathrm{Fe}^{2+}$ to scavenge free radicals and interrupt free radical chain reactions [119]. In addition, they have been able to prevent low density lipoprotein (LDL) oxidation induced by different oxidizing agents $[120,121]$ and prevent DNA damage in vitro [122]. The main CGA in coffee 5-CQA was able to scavenge 1,1-diphenyl-2-picrylhydrazyl (DPPH) radicals, superoxide anions $\left(\mathrm{O}^{-}\right)$, hydroxyl radicals $(\cdot \mathrm{OH})$, and peroxylnitrite $\left(\mathrm{ONOO}^{-}\right)$[123-125] and to protect DNA from damage caused by oxidative stress in different studies [111,126]. Caffeic acid, one of the first and main CGA metabolites, as well as other phenolic derivatives, have also been reported to have important antioxidant activity $[127,128]$.

Cell culture experiments have shown antioxidant properties of specific CGA at both the cellular and molecular levels [111]. In the human keratinocyte cell line (HaCaT cells), 5-CQA was found to protect against $\mathrm{H}_{2} \mathrm{O}_{2}$-induced UVB-mediated oxidative stress [124]. In a culture of mesenchymal stem cells of bone marrow under oxidative stress, 5-CQA suppressed reactive oxygen species increased by activation of Akt phosphorylation and increased the expression of FOXO (Forkhead box proteins) family genes. These proteins are a family of transcription factors that play important roles in regulating the expression of genes involved in cell growth, proliferation, differentiation, and longevity [126]. CGA (5-CQA) also reduced apoptosis in primary cortical neurons by upregulating antioxidant enzymes such as NADPH:quinine oxidoreductase 1 [129]. The same compound, as well as 3-CQA and 4-CQA were found to protect murine adrenal cells against hydrogen peroxide-induced apoptosis by suppressing the mitochondrial membrane depolarization caused by oxidative stress [130]; moreover, both 5-CQA and 3,5-diCQA exerted protective effect against generation of t-butyl hydroperoxide-induced reactive oxygen species in model liver cancer HepG2 cells [131]. Feeding diabetic rats with 5-CQA effectively reduced lipid hydroperoxide production and increased the level of non-enzymatic antioxidants such as reduced glutathione and vitamins C and E [132,133]. Other studies have shown that 5-CQA can alleviate the oxidative stress induced by methamphetamine in rats by restoring liver superoxide dismutase and glutathione peroxidase activities and by preventing the accumulation of lipid peroxidation [134]. As aforementioned, there is strong evidence that CGA are effective in protecting against oxidation reactions in vivo by upregulating redox-related nuclear transcription factors involved in the expression of antioxidant enzymes [111].

Despite the high antioxidant activity of coffee or its capacity to upregulate antioxidant enzymes, in addition to any other health attribute it might have, it is noteworthy mentioning that this does not mean that CGA from coffee or coffee itself can replace the intake of antioxidants from other foods, as each has its own specific bioactivity [35].

\section{Anti-Inflammatory Effect and Wound Healing}

Oxidative stress and chronic inflammation are closely related physio-pathological events [135]. Experimental data show the simultaneous existence of low-grade chronic inflammation and oxidative stress in many chronic diseases like diabetic complications, cardiovascular and neurodegenerative diseases, alcoholic liver disease, and chronic kidney disease [136-138]. Inflammation is a complex 
physiological reaction to tissue injury caused by exogenous or endogenous sources [111]. Exaggerated or unregulated prolonged inflammatory process can induce tissue damage and is the cause for many chronic diseases [139].

Most evidences to date show that 5-CQA exerts anti-inflammatory activity by downregulating pro-inflammatory cytokines, through modulation of key transcription factors, such as tumor necrosis factor-alpha (TNF- $\alpha$ ), and interleukins such as IL-8 [111,140]. A cell study conducted on murine RAW 264.7 macrophages indicated that 5-CQA decreased lipopolysaccharide (LPS)-induced upregulation of cyclooxygenase (COX-2) at protein and mRNA levels suggesting that 5-CQA could exert anti-inflammatory effects through inhibiting prostaglandin E2 (PGE2) production [141].

In animal studies, the oral administration of 5-CQA protected against trinitrobenzenesulfonic acid-induced colitis in mice by reducing neutrophil infiltration and inhibiting the NF- $\mathrm{KB}$ (factor nuclear kappa B) pathway [142]. A similar effect was also observed in the dextran sulfate sodium-induced colitis model in mice [136]. In both cases, suppression of pro-inflammatory cytokines was observed. CGA (5-CQA) could effectively prevent mice from concanavalin A-induced hepatitis, which might have resulted from the activation of Toll-Like Receptor (TLR) 4 signaling, downregulating the expression of adhesion molecules, and also alleviating the infiltration and activation of hepatic leukocytes and the production of pro-inflammatory cytokines [143].

The reduction of inflammation resulting in enhanced wound healing has also been reported for CGA in different studies [111]. In a study with diabetic rats, the oral administration of 5-CQA enhanced hydroxyproline and decreased malondialdehyde/nitric oxide levels in wound tissues, in addition to elevating reduced-glutathione $[143,144]$. Another in vivo study using a mice skin excision wound showed that topically administrated hydrogels containing 5-CQA reduced significantly the wound area size in the inflammatory phase, enhancing the wound healing process [145].

\section{Antimutagenic and Anticarcinogenic Effects}

This activity is partly related to CGA antioxidant activity, since the overproduction of oxygen free radicals lead to oxidative damage of DNA which is primarily responsible for promoting various types of cancer as breast, bladder, colon, liver, pancreatic, prostate, and skin cancers [146]. Dietary polyphenols, including CGA, can prevent the initiation step of cancer by inhibition of DNA-damage caused by free radicals or carcinogenic agents [147]. In fact, epidemiological studies show an inverse association between coffee consumption and the risk of certain types of cancer. Such effect has been related to CGA intake [148-150].

The anti-mutagenic property of CGA and their metabolites has been demonstrated decades ago [151]. Recent studies have confirmed these findings and elucidated several mechanisms of chemo-preventive action [35]. They include modulation of expression of enzymes involved in endogenous antioxidant defenses, DNA replication, cell differentiation and ageing [147,152,153], metal chelation, inactivation of reactive compounds, and metabolic pathway changes [154]. In the colon, for example, 5-CQA may inactivate free reactive radicals from diet and as a result help preventing colon cancer [155]. In epithelial JB6 cells from mice, 5-CQA decreased reactive oxygen species generation and stimulated glutathione-S-transferase activity, providing a protective role against carcinogens [152]. Coffees rich in CGA induced chemo preventive phase II-enzymes via the Nrf2/ARE pathway (important mechanism for protecting cells and tissues from carcinogenesis and carcinogenic metabolites) in vitro and in vivo [156].

\section{Hepatoprotective Effect}

Hepatic injury may result from many different causes, including viral hepatitis, iron overload, obesity, and excessive alcohol consumption [111]. The beneficial impacts of coffee on liver diseases in general have been reported in several studies [157-159]. They include hepatitis B and C [160] and cirrhosis [158]. Additionally, according to meta-analysis of 16 human studies, coffee consumption ( 2 cups/day) reduces the risk of developing liver cancer by $40 \%$ as compared to no coffee 
consumption [161,162]. Proposed protective mechanisms are prevention of cell apoptosis and oxidative stress damage due to activation of natural antioxidant and anti-inflammatory systems $[163,164]$. Such protective mechanisms have been linked mainly with CGA [165] and caffeine [166] among other coffee compounds. In general, experimental data suggest that the hepatoprotective activity of CGA is probably associated with an inflammatory response inhibition [167] and anti-viral activity [160].

$\mathrm{Xu}$ et al. [168] administered intraperitoneal 5-CQA to C57BL/6J mice (with lipopolysaccharideinduced inflammatory liver injury) and observed that the expression of TNF- $\alpha$ was markedly inhibited, suggesting anti-inflammatory effect of 5-CQA on acute liver injury. Yun et al. [164] examined the effects of 5-CQA on hepatic ischemia/reperfusion (I/R) injury in rats. In 5-CQA treated rats, the levels of serum TNF- $\alpha$, inducible nitric oxide synthase and cyclooxygenase- 2 protein was significantly reduced, and hepatic histology was improved, suggesting the positive effect of CGA on I/R-induced liver injury.

The anti-fibrotic effect of 5-CQA oral administration on CC14-rats with induced cirrhosis was investigated by Shi et al. [169]. CGA (5-CQA) reduced liver fibrosis as well as the expression of collagens I and III. Consistently, rats treated with 5-CQA displayed reduced levels of vascular endothelial growth factor, tissue growth factor- $\beta$ and $\alpha$-smooth muscle actin, thus indicating that 5-CQA was able to counteract liver fibrogenesis in rats. Successively, the same authors further extended their findings on the anti-fibrotic effects of 5-CQA in the same experimental model by showing that 5-CQA treatment reduces the expression of inflammatory cytokines, TLR 4, myeloid differentiation factor 88, inducible nitric oxide synthase, and activation of cyclooxygenase- 2 and nuclear factor- $\mathrm{kB}$ [170]. These are just a few among the many positive studies on the hepatoprotective effect of coffee and CGA.

\section{Anti-Diabetic Effect}

Epidemiological studies suggest that coffee consumption prevents or delays the onset of type 2 diabetes [171,172]. Studies concluded that daily consumption of 3-4 cups of coffee a day might exert such health effects by reducing oxidative damage, body fat mass, and energy/nutrient uptake [173,174]. These beneficial effects have been attributed mainly to CGA and derivatives [175] as well as trigonelline $[176,177]$. They appear to target preferentially hepatic glucose metabolism by improving whole body insulin sensitivity [178-180]. Additionally, a synthetic derivative of 5-CQA (S3483) inhibited the glucose-6-phosphate system and subsequently delayed glucose absorption in the intestine [111,181]. Other proposed mechanisms observed in vivo and in vitro are related to the regulation of key enzymes of glucose and lipid metabolism, such as glucokinase, fatty acid synthase, and carnitine palmitoyl transferase [182]. CGA lactones have also been able to increase hepatic and muscle glucose utilization among other mechanisms that result in lowering the blood glucose levels in rats [183].

\section{Cardioprotective and Antihypertensive Effects}

Cardiovascular diseases are the leading cause of death in the world according to the World Health Organization (WHO), with $13.2 \%$ and $2 \%$ of deaths due to ischaemic and hypertensive cardiovascular diseases, respectively [184]. Key mechanisms for cardiovascular protection are high antioxidant and anti-inflammatory properties which improve endothelial dysfunction and reduce insulin resistance. CGA exhibit both of these properties and a number of in vitro studies have demonstrated a positive role against endothelial dysfunction [111]. Another mechanism for CGA protective effects on vascular endothelial function is the release of vasoactive molecules such as nitric oxide [185] and decrease in plasma total homocysteine levels [186]. Additionally, studies indicate that 5-CQA and caffeic acid have beneficial effects on cardiovascular diseases via suppressing P-selectin expression on platelets. Potential effects on P-selectin expression were suggested to derive from their significant involvement in platelet activation [187]. In respect to effects of CGA on blood pressure, several mechanisms have been proposed, including the stimulation of nitric oxide production through the 
endothelial-dependent pathway [188], reduction of free radicals through inhibiting NAD(P)H oxidase expression and activity [189], and inhibition of angiotensin-converting enzyme [111].

\section{Antiobesity and Anti-Metabolic Syndrome Effects}

The oxidative stress accumulated in fat tissue has been proposed as an early initiator of the obesity-associated metabolic syndrome [190,191] which is defined as a group of interconnected physiological, biochemical, clinical, and metabolic factors that increase the risk of cardiovascular diseases, type 2 diabetes, and all-cause mortality [192]. Chronic inflammation has also been associated with the underlying cause of dysregulation of adipocytokines and development of metabolic syndrome [112,193]. CGA exert both antioxidant and anti-inflammatory properties, being promising candidates to help prevent and fight metabolic syndrome.

Habitual coffee consumption (1-4 cups/day) has been inversely associated with metabolic syndrome $[194,195]$. Moreover, epidemiological evidence suggests that the consumption of coffee is inversely associated with weight gain [196]. In two prospective cohort studies, the consumption of both regular and decaffeinated coffees was associated with body weight loss [196,197], which suggests a positive effect of non-caffeine coffee compounds on weight reduction, with CGA being the strongest candidate [198]. In fact, decaffeinated green CGA-rich coffee extracts have been marketed for such purposes.

Several mechanisms related to the antioxidant and anti-inflammatory properties of CGA have been proposed to explain how these compounds exert positive effects over metabolic syndrome [191]. Ma et al. [199] found that 5-CQA treatment in obese mice fed a high-fat diet greatly inhibited the diet reduced expression of macrophage marker genes $F 4 / 80, C d 68, C d 11 b$ and $C d 11 c$ in adipose tissue, aand of and pro-inflammatory mediator genes (TNF- $\alpha$ and MCP-1) in macrophages. In addition, the authors observed that 5-CQA inhibited hepatic peroxisome proliferator-activated receptor $\gamma$ (PPAR $\gamma$ ), which promotes fatty acid uptake into liver cells. The mechanism proposed was that 5-CQA scavenges reactive oxygen species (ROS) generated by consumption of high-fat diet, which suppresses the expression of inflammation, and consequently reduces fat accumulation, weight gain, and insulin resistance, while inhibition of PPAR $\gamma$ prevents and improves liver steatosis [191]. Furthermore, 5-CQA has been observed to have an impact over important transcription factors and enzymes that regulate lipid metabolism, which has been associated to positive effects on obesity and dyslipidemia [191,200]. The anti-obesity properties of CGA have also been linked to the metabolism of glucose $[200,201]$. CGA (5-CQA) was responsible for a significant improvement in glucose tolerance that might be a consequence of reduction in body mass index and its effects on body weight [202]. In mice, 5-CQA has been suggested to reduce body weight by inhibiting hepatic triglyceride accumulation [203]. The mechanism via enhanced lipolytic activity in the adipocyte tissue has also been related to the effects on adipocyte metabolism and weight reduction [111,204].

Recently, 5-CQA showed promising effects in modulating lipid metabolism and decreasing obesity in high-fat diet induced rats, which could be attributed to the reduction in hepatic lipogenesis and hepatic fatty acid uptake, as well as the enhancement of hepatic fatty acid $\beta$-oxidation. The mechanism of 5-CQA action was associated with upregulation of peroxisome proliferator-activated receptor $\alpha$ $(\operatorname{PPAR} \alpha)$ expression and downregulation of liver $\mathrm{X}$ receptor $\alpha(\mathrm{LXR} \alpha)$ expression. Additionally, enhancement of the antioxidant activity and clearance of free fatty acids also contributed to the effect of 5-CQA [205].

\section{Neuroprotective Effects}

Alzheimer's disease is the most frequent cause of dementia, leading to a progressive cognitive decline. While there is currently no medication against Alzheimer's disease [182], several studies have observed an inverse association between regular coffee consumption and development of Alzheimer's disease [35,36]. The mechanisms of coffee protective effect are believed to be related to the anti-inflammatory effects of caffeine and CGA on the A1 and A2 receptors as well as to the 
reduction of toxic $\beta$-amyloid peptide deposits in the brain, a pathological characteristic in patients with Alzheimer's disease [206-209]. Other proposed mechanisms could be the inhibition of the enzyme's acetylcholinesterase and butyrylcholinesterase in the brain (given that such inhibition retards acetylcholine and butyrylcholine breakdown), and prevention of oxidative stress-induced neurodegeneration due to its high antioxidative activity [206-208].

Emerging evidence from animal models also link CGA to prevention against other neurodegenerative diseases and ageing [210,211]. Although the involvement of coffee polyphenols in human cognitive function has not been well studied, the number of findings on the in vitro neuroprotective effects of polyphenols in general is rapidly increasing [212]. Shen et al. [213] reported that the intraperitoneal injection of 5-CQA decreased oxidative damage in rat brain cerebellum exposed to methotrexate, a drug with severe side effects used to treat certain types of cancer, psoriasis, and rheumatoid arthritis. They found that 5-CQA pre-treatment attenuated lipopolysaccharide (LPS)-induced IL- $1 \beta$ and (TNF- $\alpha$ ) release in the substantia nigra, thereby pointing to the neuroprotective effects of 5-CQA on pro-inflammatory cytokine-mediated neurodegenerative disease. In another study by Taram et al. [214], the neuroprotective effects of 5-CQA and major metabolites caffeic and ferulic acids were investigated in primary cultures of rat cerebellar granule neurons and it was suggested that caffeic acid displays a much broader profile of neuroprotection against a diverse range of stressors than its parent 5-CQA or ferulic acid. The authors concluded that caffeic acid is a promising candidate for testing in pre-clinical models of neurodegeneration.

The anxiolytic and mood-elevating properties of 5-CQA have been reported. The anti-anxiety effect was blocked by flumazenil, suggesting that such an effect by 5-CQA is dependent on its activity on GABAA-benzodiazepine receptors [215]. Also, CGA' positive effects on inflammation are consistent with those outlined in the neuroinflammatory hypotheses of depression and with the effects of current antidepressant therapies. In the same way, due to the aforementioned positive CGA effects on the central nervous system, they may play a part in decreasing depressive symptoms. However, to date, there is insufficient evidence to confirm this hypothesis [216].

Regarding CGLs, they hold the same antioxidant property as their CGA precursors and as they are less polar, they should be more permeable to the blood-brain barrier. They have been shown to bind to specific sites in the brain, including $\mu$-opioid receptors [13,14]. A significant correlation between CGL concentration in coffee and neuron cell survival in a hydrogen peroxide-induced neuron death model has been reported [217], suggesting a possible contribution of CGL to the increased neuron protective effects.

\section{Antimicrobial Effect}

A number of studies have reported antimicrobial (bacteriostatic and bactericidal) effects of 5-CQA and coffee extracts on various types of detrimental microorganisms that may grow in different parts of the body, from oral bacteria causative of caries to detrimental intestinal bacteria. Roasted C. arabica and C. canephora extracts and brews showed antibacterial activity against Streptococcus mutans and other oral types of bacteria $[218,219]$. CGA $(5-C Q A)$ was shown to contribute to such activity, with minimum inhibitory effect (MIC) varying in the different studies from 0.8 to $5.0 \mathrm{mg} / \mathrm{mL}[218,219]$. Bactericidal effect was found against the intestinal bacteria Stenotrophomonas maltophilia resistant to trimethoprim/sulfamethoxazole [220], Helicobacter pylori [221], Staphylococcus epidermidis [222], Streptococcus pneumoniae, Staphylococcus aureus, Bacillus subtilis, Escherichia coli, Shigella dysenteriae, Salmonella Typhimurium [223], Klebsiella pneumonia [224].

In addition to 5-CQA, bacteriostatic and bactericidal effects of CGA colonic metabolites (ferulic, isoferulic, benzoic, and hydroxybenzoic acids) have been observed against Escherichia coli [225,226]. Minimum inhibitory effect for caffeic acid and other CGA metabolites varied from 0.6 to $80 \mathrm{mg} / \mathrm{mL}$ in different studies for different types of microorganisms [221-224]. The mechanism for antimicrobial action of 5-CQA has been suggested to be binding to the outer cell membrane and disruption of it, exhaustion of intracellular potential, and release of cytoplasm macromolecules, leading to cell 
death [223]. Especially in the context of knowledge about the positive effects of 5-CQA against detrimental colon microflora, it has been suggested that the potent and selective antimicrobial effect of 5-CQA makes it suitable as an ideal food preservative and additive [113].

CGA can also exert antifungal effects against Candida albicans by disrupting the fungi's cell membrane [227]. Both caffeic acid and 5-CQA are known to have multi-antiviral activities against Herpes simplex virus (HSV) types 1 and 2 [228], HIV virus [229], and adenovirus [230]. Potent antiviral activity of 5-CQA against Ebola virus have also been observed [231,232].

\section{Potential Prebiotic Effect}

The consumption of prebiotic foods or compounds stimulate the growth of probiotic and other health promoting colonies in the intestine, with special emphasis given to Bifidobacterium and Lactobacillus spp. $[233,234]$. Therefore, indirectly, the literal benefits of prebiotics to health are the same as those of probiotics, such as production of short-chain fatty acids which decrease the luminal $\mathrm{pH}$, stimulating the growth of beneficial intestinal bacteria and suppressing pathogenic bacteria [233,234], stimulating the immune system [235,236], preventing colon cancer [237], increasing calcium absorption [238], and preventing diabetes [239-242]. Furthermore, dietary supplementation with prebiotics may reduce or retard the accumulation of advanced glycation end products (AGE) formed via Maillard reaction in individuals at risk of type 2 diabetes, and also, improve and restore microbial balance within the gastrointestinal tract, potentially reducing AGE absorption [243].

Reported data suggest that the unabsorbed portion of CGA and caffeic acid in the human gastrointestinal tract serves as a substrate for beneficial intestinal bacteria, stimulating their growth $[35,244,245]$. While the bifidogenic effect of CGA seems to be a consensus [246,247], CGA effect on the multiplication of Lactobacillus spp. is somewhat controversial, suggesting growth of selected strains $[226,247]$. In most studies evaluating the prebiotic effects of 5-CQA, increase in short-chain fatty acids production has been observed [246]. However, differently from the classical prebiotic frutooligosaccharide, incubation with 5-CQA has promoted the growth of Firmicutes and Bacteroides, and of Clostridium coccoides-Eubacterium rectale groups as well [247]. Also, the effect of 5-CQA on the growth of E. coli does not seem to be clear, being effective in decreasing the number of colonies in just a few studies [223]. In conclusion, the number of studies on the prebiotic effects of CGA is small but the existing data are promising, although not all the effects observed for classical prebiotic compounds are observed. The physiological and clinical outcomes from such differences need to be evaluated. Also, the prebiotic effect of CGA compounds other than 5-CQA needs to be evaluated.

\section{Concluding Remarks}

The contribution of CGA to the daily polyphenol and antioxidant intake for coffee drinkers is quite relevant. Several studies have demonstrated that CGA are partially bioavailable and potentially beneficial to human health. However, considering that their concentration in coffee beverage depends on a number of factors, that a considerable inter-individual variability occurs in the metabolism of these compounds in humans, and that the ingested amount necessary to promote each of their potential health benefits is still unknown, more studies are needed in order to establish a daily dietary recommendation aiming at specific health benefits. Studies are also needed to elucidate the mechanisms involved in the absorption and metabolism of individual major and minor CGA compounds from coffee. Because only a few CGA are commercially available or synthesized in laboratories, studies on the bioavailability and biological properties of CGL, FQA, $p$-CoQA, CFQA (caffeoyl-feruloylquinic acid), and other minor CGA compounds are missing. Lastly, studies on the interactions of food components with CGA are also needed. 
Funding: This research was funded by the Rio de Janeiro State Research Support Foundation (FAPERJ: Grant number E-02/2017\# 234092).

Acknowledgments: The authors would like to acknowledge the scholarships provided by the National Council for Scientific and Technological Development (CNPq, Brazil reg. \#309091/2016-0) and the Rio de Janeiro State Research Support Foundation (FAPERJ: E-02/2017\# 234092).

Conflicts of Interest: The authors declare no conflict of interest.

\section{References}

1. Robiquet, P.J. Ueber den Kaffee. Ann. Pharm. 1837, 23, 93-95. [CrossRef]

2. Barnes, H.M.; Feldman, J.R.; White, W.V. Isochlorogenic Acid. Isolation from Coffee and Structure Studies. J. Am. Chem. Soc. 1950, 72, 4178-4182. [CrossRef]

3. IUPAC. Nomenclature of cyclitols. Biochem. J. 1976, 153, 23-31. [CrossRef]

4. Moores, R.G.; McDermott, D.L.; Wood, T.R. Determination of Chlorogenic Acid in Coffee. Anal. Chem. 1948, 20, 620-624. [CrossRef]

5. Kremr, D.; Bajer, T.; Bajerová, P.; Surmová, S.; Ventura, K. Unremitting problems with chlorogenic acid nomenclature: A review. Quim. Nova 2016, 39, 530-533. [CrossRef]

6. Ukers, W.H. All About Coffee; The Tea and Coffee Trade Journal Company: New York, NY, USA, $1922 ;$ p. 796.

7. Corse, J.R.E.; Lundin, A.C.; Wais, J.R. Identification of several components of isochlorogenic acid. Phytochemistry 1965, 4, 527-529. [CrossRef]

8. Trugo, L.C. HPLC in Coffee Analysis. Ph.D. Thesis, University of Reading, Reading, UK, 1984.

9. Wynne, K.N.; Familari, M.; Jaroslav, H.; Boublik, J.; Drummer, O.H.; Rae, I.D.; Funder, J.W. Isolation of opiate receptor ligands in coffee. Clin. Exp. Pharmacol. Physiol. 1987, 14, 785-790. [CrossRef] [PubMed]

10. Scholz-Bottcher, B.M.; Maier, H.G. Isomers of quinic acid and quinides in roasted coffee: Indicators for the degree of roast'? In Proceedings of the International Conference on Coffee Science (ASIC), San Francisco, CA, USA, 14-19 July 1991.

11. Bennat, C.; Engelhardt, U.H.; Kiehne, A.; Wirries, F.M.; Maier, H.G.Z. HPLC Analysis of chlorogenic acid lactones in roasted coffee. Zeitschrift für Lebensmittel-Untersuchung und Forschung 1994, 199, 17-21. [CrossRef]

12. Schrader, K.; Kiehne, A.; Engelhardt, U.H.; Maier, H.G. Determination of chlorogenic acids with lactones in roasted coffee. J. Sci. Food Agric. 1996, 71, 392-398. [CrossRef]

13. De Paulis, T.; Commers, P.; Farah, A.; Zhao, J.; McDonald, M.P.; Galici, R.; Martin, P.R. 4-Caffeoyl-1,5-quinide in roasted coffee inhibits $[3 \mathrm{H}]$ naloxone binding and reverses anti-nociceptive effects of morphine in mice. Psychopharmacology 2004, 176, 146-153. [CrossRef]

14. De Paulis, T.; Schmidt, D.E.; Bruchey, A.K.; Kirby, M.T.; McDonald, M.P.; Commers, P.; Lovinger, D.M.; Martin, P.R. Dicinnamoylquinides in roasted coffee inhibit the human adenosine transporter. Eur. J. Pharmacol. 2002, 442, 215-223. [CrossRef]

15. Clifford, M.N.; Knight, S. The cinnamoyl-amino acid conjugates of green robusta coffee beans. Food Chem. 2004, 87, 457-463. [CrossRef]

16. Clifford, M.N.; Marks, S.; Knight, S.; Kuhnert, N. Characterization by LC-MS(n) of four new classes of p-coumaric acid-containing diacyl chlorogenic acids in green coffee beans. J. Agric. Food Chem. 2006, 54, 4095-4101. [CrossRef]

17. Clifford, M.N.; Knight, S.; Surucu, B.; Kuhnert, N. Characterization by LC-MS(n) of four new classes of chlorogenic acids in green coffee beans: Dimethoxycinnamoylquinic acids, diferuloylquinic acids, caffeoyl-dimethoxycinnamoylquinic acids, and feruloyl-dimethoxycinnamoylquinic acids. J. Agric. Food Chem. 2006, 54, 1957-1969. [CrossRef]

18. Jaiswal, R.; Kuhnert, N. Hierarchical scheme for liquid chromatography/multi-stage spectrometric identification of 3,4,5-triacyl chlorogenic acids in green Robusta coffee beans. Rapid Commun. Mass Spectrom. 2010, 24, 2283-2294. [CrossRef] [PubMed]

19. Jaiswal, R.; Patras, M.A.; Eravuchira, P.J.; Kuhnert, N. Profile and characterization of the chlorogenic acids in green Robusta coffee beans by LC-MS(n): Identification of seven new classes of compounds. J. Agric. Food Chem. 2010, 58, 8722-8737. [CrossRef] [PubMed] 
20. Kuhnert, N.; Karaköse, H.; Jaiswal, R. Analysis of chlorogenic acids and other hydroxycinnamates in food, plants, and pharmacokinetic studies. In Handbook of Analysis of Active Compounds in Functional Foods; Nollet, L.M.L., Toldrae, F., Eds.; CRC Press: Boca Raton, FL, USA, 2012; pp. 461-506. ISBN 9781439815885.

21. Matei, M.F.; Jaiswal, R.; Kuhnert, N.J. Investigating the chemical changes of chlorogenic acids during coffee brewing: Conjugate addition of water to the olefinic moiety of chlorogenic acids and their quinides. J. Agric. Food Chem. 2012, 60, 1205-1215. [CrossRef] [PubMed]

22. Jaiswal, R.; Matei, M.F.; Golon, A.; Witt, M.; Kuhnert, N. Understanding the fate of chlorogenic acids in coffee roasting using mass spectrometry based targeted and non-targeted analytical strategies. Food Funct. 2012, 3, 976-984. [CrossRef]

23. Abrankó, L.; Clifford, M.N. An unambiguous nomenclature for the acyl-quinic acids commonly known as chlorogenic acids. J. Agric. Food Chem. 2017, 65, 3602-3608. [CrossRef]

24. Clifford, M.N.; Jaganath, I.B.; Ludwig, I.A.; Crozier, A. Chlorogenic acids and the acyl-quinic acids: Discovery, biosynthesis, bioavailability and bioactivity. Nat. Prod. Rep. 2017, 34, 1391-1421. [CrossRef]

25. Clifford, M.N. Chlorogenic acids and other cinnamates-nature, occurrence and dietary burden. J. Sci. Food Agric. 1999, 79, 362-372. [CrossRef]

26. Meinhart, A.D.; Damin, F.M.; Caldeirão, L.; da Silveira, T.F.F.; Filho, J.T.; Godoy, H.T. Chlorogenic acid isomer contents in 100 plants commercialized in Brazil. Food Res. Int. 2017, 99, 522-530. [CrossRef] [PubMed]

27. Farah, A.; Lima, J.P. Major chlorogenic acids' contents and distribution in coffees. In Coffee: Production, Quality and Chemistry; Royal Society of Chemistry: London, UK, 2018; in press; ISBN 978-1782620044.

28. Tfouni, S.A.V.; Carreiro, L.B.; Teles, C.R.A.; Furlani, R.P.Z.; Cipolli, K.M.V.A.B.; Camargo, M.C.R. Caffeine and chlorogenic acids intake from coffee brew: Influence of roasting degree and brewing procedure. Int. J. Food Sci. Technol. 2014, 49, 747-752. [CrossRef]

29. Niseteo, T.; Komes, D.; Belščak-Cvitanović, A.; Horžić, D.; Budeč, M. Bioactive composition and antioxidant potential of different commonly consumed coffee brews affected by their preparation technique and milk addition. Food Chem. 2012, 134, 1870-1877. [CrossRef] [PubMed]

30. Crozier, T.W.M.; Stalmach, A.; Lean, M.E.J.; Crozier, A. Espresso coffees, caffeine and chlorogenic acid intake: Potential health implications. Food Funct. 2012, 3, 30-33. [CrossRef] [PubMed]

31. Ludwig, I.A.; Mena, P.; Calani, L.; Cid, C.; Del Rio, D.; Leand, M.E.J.; Crozier, A. Variations in caffeine and chlorogenic acid contents of coffees: What are we drinking? Food Funct. 2014, 5, 1718-1726. [CrossRef] [PubMed]

32. Angeloni, G.; Guerrini, L.; Masella, P.; Bellumori, M.; Daluiso, S.; Parenti, A.; Innocenti, M. What kind of coffee do you drink? An investigation on effects of eight different extraction methods. Food Res. Int. 2018, in press. [CrossRef]

33. Bastos, I.P.N. Influência dos métodos de preparo e granulometria do café sobre os teores de ácidos clorogênicos e lactonas na bebida e sobre a preferência do consumidor. Master's Thesis, Federal University of Rio de Janeiro, Rio de Janeiro, Brazil, 2012.

34. Farah, A.; Lima, J.P. Chlorogenic acids: Daily consumption through coffee, metabolism and potential health effects. In Coffee: Consumption and Health Implications; Royal Society of Chemistry: London, UK, 2018; in press; ISBN 978-1782620044.

35. Farah, A. Nutritional and health effects of coffee. In Achieving Sustainable Cultivation of Coffee; Lashermes, P., Ed.; Burleigh Dodds Science Publishing: Cambridge, UK, 2017; pp. 1-31. ISBN 978-1-78676-152-1.

36. Folmer, B.; Farah, A.; Jones, L.; Fogliano, V. Human Wellbeing, Sociability, Performance and Health. In The Craft and Science of Coffee; Folmer, B., Ed.; Elsevier: Cambridge, UK, 2017; pp. 493-520.

37. Trugo, L.C.; Macrae, R. Chlorogenic acid composition of instant coffees. Analyst 1984, 109, $263-266$. [CrossRef] [PubMed]

38. Clifford, M.N. Chemical and physical aspects of green coffee and coffee products. In Coffee: Botany, Biochemistry and Production of Beans and Beverage; Clifford, M.N., Willson, K.C., Eds.; Chroom Helm: Sydney, Australia, 1987; pp. 305-374. ISBN 978-1-4615-6657-1.

39. Fujioka, K.; Shibamoto, T. Quantitation of volatiles and nonvolatile acids in an extract from coffee beverages: Correlation with antioxidant activity. J. Agric. Food Chem. 2006, 54, 6054-6058. [CrossRef] [PubMed]

40. Jeon, J.S.; Kim, H.T.; Jeong, I.H.; Hong, S.R.; Oh, M.S.; Park, K.H.; Shim, J.H.; Abd El-Aty, A.M. Determination of chlorogenic acids and caffeine in homemade brewed coffee prepared under various conditions. J. Chromatogr. B Anal. Technol. Biomed. Life Sci. 2017, 1064, 115-123. [CrossRef] [PubMed] 
41. Bravo, J.; Juániz, I.; Monente, C.; Caemmererb, B.; Krohb, L.W.; Paz De Peña, M.; Cid, C. Evaluation of spent coffee obtained from the most common coffeemakers as a source of hydrophilic bioactive compounds. J. Agric. Food Chem. 2012, 60, 12565-12573. [CrossRef] [PubMed]

42. Moeenfard, M.; Rocha, L.; Alves, A. Quantification of caffeoylquinic acids in coffee brews by HPLC-DAD. J. Anal. Methods Chem. 2014, 2014. [CrossRef] [PubMed]

43. Fuller, M.; Rao, N.Z. The effect of time, roasting temperature, and grind size on caffeine and chlorogenic acid concentrations in cold brew coffee. Sci. Rep. 2017, 7. [CrossRef] [PubMed]

44. Rao, N.Z.; Fuller, M. Acidity and antioxidant activity of cold brew coffee. Sci. Rep. 2018, 8. [CrossRef] [PubMed]

45. Farah, A.; Duarte, G. Metabolism and bioavailability of coffee chlorogenic acids in humans. In Coffee and Health Disease Prevention; Preedy, V.R., Ed.; Elsevier: Cambridge, UK, 2015; pp. 789-812. ISBN 9780124167162.

46. Nogueira, M.; Trugo, L.C. Distribuição de isômeros de ácido clorogênico e teores de cafeína e trigonelina em cafés solúveis brasileiros. Ciênc. Tecnol. Aliment. 2003, 23, 296-299. [CrossRef]

47. Duarte, G.S.; Farah, A. Chlorogenic acids and lactones in Brazilian commercial coffee. In Proceedings of the International Conference on Coffee Science (ASIC), Trieste, Italy, 14-18 May 2009.

48. Sanchez-Bridge, B.; Renouf, M.; Sauser, J.; Beaumont, M.; Actis-Goretta, L. The roasting process does not influence the extent of conjugation of coffee chlorogenic and phenolic acids. Biofactors 2016, 42, 259-267. [CrossRef]

49. Lima, J.P.; Farah, A. Contribution of foods for habitual daily intake of methylxanthines in Rio de Janeiro. In Proceedings of the International Conference on Coffee Science (ASIC), Armenia, Colombia, 8-13 September 2014.

50. Mills, C.E.; Oruna-Concha, M.J.; Mottram, D.S.; Gibson, G.R.; Spencer, J.P.E. The effect of processing on chlorogenic acid content of commercially available coffee. Food Chem. 2013, 141, 3335-3340. [CrossRef]

51. Floegel, A.; Pischon, T.; Bergmann, M.M.; Teucher, B.; Kaaks, B.; Boeing, H. Coffee consumption and risk of chronic disease in the European Prospective Investigation into Cancer and Nutrition (EPIC)-Germany study. Am. J. Clin. Nutr. 2012, 95, 901-908. [CrossRef]

52. Torres, T.; Farah, A. Coffee, maté, açaí and beans are the main contributors to the antioxidant capacity of Brazilian's diet. Eur. J. Nutr. 2017, 56, 1523-1533. [CrossRef]

53. International Coffee Organization. World Coffee Consumption. Available online: http://www.ico.org/ prices/new-consumption-table.pdf (accessed on November 18th 2018).

54. Park, S.Y.; Freedman, N.D.; Haiman, C.A.; Marchand, L.L.; Wilkens, L.R.; Setiawan, V.W. Association of coffee consumption with total and cause-specific mortality among nonwhite populations. Ann. Intern. Med. 2017, 167, 228-235. [CrossRef]

55. Poole, R.; Kennedy, O.J.; Roderick, P.; Fallowfield, J.A.; Hayes, P.C.; Parkes, J. Coffee consumption and health: Umbrella review of meta-analyses of multiple health outcomes. BMJ 2017, 359. [CrossRef] [PubMed]

56. O'Keefe, J.H.; Bhatti, S.K.; Patil, H.R.; DiNicolantonio, J.J.; Lucan, S.C.; Lavie, C.J. Effects of habitual coffee consumption on cardiometabolic disease, cardiovascular health, and all-cause mortality. J. Am. Coll. Cardiol. 2013, 62, 1043-1051. [CrossRef] [PubMed]

57. Scientific American. How Is Caffeine Removed to Produce Decaffeinated Coffee? Available online: https: / / www.scientificamerican.com/article/how-is-caffeine-removed-t/ (accessed on 18 November 2018).

58. Saura-Calixto, F.; Goni, I. Antioxidant capacity of the Spanish Mediterranean diet. Food Chem. 2006, 94, 442-447. [CrossRef]

59. Brazilian Institute of Geography and Statistics. 2017. Available online: https://www.ibge.gov.br/apps / populacao/projecao/ (accessed on 18 November 2018).

60. Grosso, G.; Stepaniak, U.; Topor-Madry, R.; Szafraniec, K.; Pajak, A. Estimated dietary intake and major food sources of polyphenols in the Polish arm of the HAPIEE study. Nutrition 2010, 30, 1398-1403. [CrossRef] [PubMed]

61. The Environment and Food Agency of Iceland. Caffeine Consumption in Iceland in 2002; The Environment and Food Agency of Iceland, Office of Food: Reykjavík, Iceland, 2004.

62. Svilaas, A.; Sakhi, A.K.; Andersen, L.F.; Svilaas, T.; Ström, E.C.; Jacobs, D.R.; Blomhoff, R. Intakes of antioxidants in coffee, wine, and vegetables are correlated with plasma carotenoids in humans. J. Nutr. 2004, 134, 562-567. [CrossRef] [PubMed] 
63. Ruusunen, A.; Lehto, S.M.; Tolmunen, T.; Mursu, J.; Kaplan, G.A.; Voutilainen, S. Coffee, tea and caffeine intake and the risk of severe depression in middle-aged Finnish men: The Kuopio Ischaemic Heart Disease Risk Factor Study. J. Nutr. 2004, 134, 562-567. [CrossRef] [PubMed]

64. Bizzo, M.L.G.; Farah, A.; Kemp, J.A.; Scancetti, L.B. Highlights in the History of Coffee Science Related to Health. In Coffee and Health Disease Prevention; Preedy, V.R., Ed.; Elsevier: Cambridge, UK, 2015; pp. 11-17. ISBN 9780124167162.

65. Booth, A.N.; Emerson, O.H.; Jones, F.T.; Deeds, F. Urinary metabolites of caffeic and chlorogenic acids. J. Biol. Chem. 1957, 229, 51-59. [PubMed]

66. Spencer, J.P.; Chowrimootoo, G.; Choudhury, R.; Debnam, E.S.; Srai, S.K.; Rice-Evans, C. The small intestine can both absorb and glucuronidate luminal flavonoids. FEBS Lett. 1999, 458, 224-230. [CrossRef]

67. Bourne, L.C.; Rice-Evans, C.A. Urinary detection of hydroxycinnamates and flavonoids in humans after high dietary intake of fruit. Free Radic. Res. 1998, 28, 429-438. [CrossRef] [PubMed]

68. Dupas, C.; Baglieri, A.M.; Ordonaud, C.; Tom, D.; Maillard, M. Chlorogenic acid is poorly absorbed, independently of the food matrix: A Caco-2 cells and rat chronic absorption study. Mol. Nutr. Food Res. 2006, 50, 1053-1060. [CrossRef] [PubMed]

69. Monteiro, M.; Farah, A.; Perrone, D.; Trugo, L.C.; Donangelo, C. Chlorogenic acid compounds from coffee are differentially absorbed and metabolized in humans. J. Nutr. 2007, 137, 2196-2221. [CrossRef] [PubMed]

70. Farah, A.; Monteiro, M.; Donangelo, C.M.; Lafay, S. Chlorogenic acids from green coffee extract are highly bioavailable in humans. J. Nutr. 2008, 138, 2309-2315. [CrossRef] [PubMed]

71. Stalmach, A.; Mullen, W.; Barron, D.; Uchida, K.; Yokota, T.; Cavin, C.; Steiling, H.; Williamson, G.; Crozier, A. Metabolite profiling of hydroxycinnamate derivatives in plasma and urine after the ingestion of coffee by humans: Identification of biomarkers of coffee consumption. Drug Metab. Dispos. 2009, 37, 1749-1758. [CrossRef] [PubMed]

72. Renouf, M.; Guy, P.; Marmet, C.; Longet, K.; Fraering, A.; Moulin, J.; Barron, D.; Dionisi, F.; Cavin, C.; Steiling, H.; et al. Plasma appearance and correlation between coffee and green tea metabolites in human subjects. Br. J. Nutr. 2010, 104, 1635-1640. [CrossRef] [PubMed]

73. Erk, T.; Williamson, G.; Renouf, M.; Marmer, C.; Stiling, H.; Dionisi, F.; Barron, D.; Melcher, R.; Richling, E. Dose-dependent absorption of chlorogenic acids in the small intestine assessed by coffee consumption in ileostomists. Mol. Nutr. Food Res. 2012, 56, 1488-1500. [CrossRef] [PubMed]

74. Stalmach, A.; Williamson, G.; Crozier, A. Impact of dose on the bioavailability of coffee chlorogenic acids in humans. Food Funct. 2014, 5, 1727-1737. [CrossRef] [PubMed]

75. Renouf, M.; Marmet, C.; Giuffrida, F.; Lepage, M.; Barron, D.; Beaumont, M.; Williamson, G.; Dionisi, F. Dose-response plasma appearance of coffee chlorogenic and phenolic acids in adults. Mol. Nutr. Food Res. 2014, 58, 301-309. [CrossRef] [PubMed]

76. Matsui, Y.; Nakamura, S.; Kondou, N.; Takasu, Y.; Ochiai, R.; Masukawa, Y. Liquid chromatographyelectrospray ionization-tandem mass spectrometry for simultaneous analysis of chlorogenic acids and their metabolites in human plasma. J. Chromatogr. B Anal. Technol. Biomed. Life Sci. 2007, 858, 96-105. [CrossRef] [PubMed]

77. Konishi, Y.; Zhao, Z.; Shimizu, M. Phenolic acids are absorbed from the rat stomach with different absorption rates. J. Agric. Food Chem. 2006, 54, 7539-7543. [CrossRef]

78. Farrel, T.L.; Dew, T.P.; Poquet, L.; Hanson, P.; Williamson, G. Absorption and metabolism of chlorogenic acids in cultured gastric epithelial monolayers. Drug Metab. Dispos. 2011, 39, 2338-2346. [CrossRef]

79. Konishi, Y.; Shimizu, M. Transepithelial transport of ferulic acid by monocarboxylic acid transporter in Caco-2 cell monolayers. Biosci. Biotechnol. Biochem. 2003, 67, 856-862. [CrossRef] [PubMed]

80. Konishi, Y.; Kobayashi, S. Transepithelial transport of chlorogenic acid, caffeic acid, and their colonic metabolites in intestinal caco-2 cell monolayers. J. Agric. Food Chem. 2004, 52, 2518-2526. [CrossRef] [PubMed]

81. Peppercorn, M.A.; Goldman, P. Caffeic acid metabolism by bacteria of the human gastrointestinal tract. J. Bacteriol. 1971, 108, 996-1000. [PubMed]

82. Couteau, D.; McCartney, A.L.; Gibson, G.R.; Williamson, G.; Faulds, C.B. Isolation and characterization of human colonic bacteria able to hydrolyse chlorogenic acid. J. Appl. Microbiol. 2001, 90, 873-881. [CrossRef] [PubMed] 
83. Williamson, G.; Clifford, M.N. Colonic metabolites of berry polyphenols: The missing link to biological activity? Br. J. Nutr. 2010, 104, 48-66. [CrossRef]

84. Reduil, K.; Smarrito-Menozzi, C.; Guy, P.; Rezzi, S.; Dionisi, F.; Williamson, G.; Nagy, K.; Renouf, M. Identification of novel circulating coffee metabolites in human plasma by liquid chromatography-mass spectrometry. J. Cromatogr. A 2011, 1218, 4678-5688. [CrossRef]

85. Gomez-Juaristi, M.; Martínez-López, S.; Sarria, B.; Bravo, L.; Mateos, R. Bioavailability of hydroxycinnamates in an instant green/roasted coffee blend in humans. Identification of novel colonic metabolites. Food Funct. 2018, 9, 331-343. [CrossRef]

86. Ozdal, T.; Capanoglu, E.; Altay, F. A review on protein-phenolic interactions and associated changes. Food Res. Int. 2013, 51, 954-970. [CrossRef]

87. Rawel, H.M.; Kroll, J.; Hohl, U.C. Model studies on reactions of plant phenols with whey proteins. Nahrung 2001, 45, 72-81. [CrossRef]

88. Sinisi, V.; Forzato, C.; Cefarin, N.; Navarini, L.; Berti, F. Interaction of chlorogenic acids and quinides from coffee with human serum albumin. Food Chem. 2015, 168, 332-340. [CrossRef]

89. Hollman, C.; Van Het Hof, K.H.; Tijburg, L.B.; Katan, M.B. Addition of milk does not affect the absorption of flavonols from tea in man. Free Radic. Res. 2001, 34, 297-300. [CrossRef] [PubMed]

90. Roura, E.; Andres-Lacueva, C.; Estruch, R.; Mata-Bilbao, M.L.; Izquierdo-Pulido, M.; Waterhouse, A.L.; Lamuela-Raventos, R.M. Milk does not affect the bioavailability of cocoa powder flavonoid in healthy human. Ann. Nutr. Metab. 2007, 51, 493-498. [CrossRef] [PubMed]

91. Duarte, G.S.; Farah, A. Effect of simultaneous consumption of milk and coffee on chlorogenic acids' bioavailability in humans. J. Agric. Food Chem. 2011, 59, 7925-7931. [CrossRef]

92. Renoulf, M.; Marmet, C.; Guy, P.; Fraering, A.; Longet, K.; Moulin, J.; Enslen, M.; Barron, D.; Cavin, C.; Dionisi, F.; et al. Nondairy creamer, but not milk, delays the appearance of coffee phenolic acid equivalents in human plasma. J. Nutr. 2010, 140, 259-263. [CrossRef]

93. Tagliazucchi, D.; Helal, A.; Verzelloni, E.; Conte, A. The type and concentration of milk increase the in vitro bioaccessibility of coffee chlorogenic acids. J. Agric. Food Chem. 2012, 60, 11056-11064. [CrossRef]

94. Scherbl, D.; Renouf, M.; Marmet, C.; Poquet, L.; Cristiani, I.; Dahbane, S.; Emandy-Azar, S.; Sauser, J.; Galan, J.; Dionisi, F.; et al. Breakfast consumption induces retarded release of chlorogenic acid metabolites in humans. Eur. Food Res. Technol. 2017, 243, 791-806. [CrossRef]

95. Felberg, I.; Farah, A.; Monteiro, M.C.; Godoy, R.L.O.; Pacheco, S.; Calado, V.; Donangelo, C.M.J. Effect of simultaneous consumption of soymilk and coffee on the urinary excretion of isoflavones, chlorogenic acids and metabolites in healthy adults. Func. Foods 2015, 19, 688-699. [CrossRef]

96. Budryn, G.; Pałecz, B.; Rachwał-Rosiak, D.; Oracz, J.; Zaczyńska, D.; Belica, S.; Navarro-González, I.; Meseguer, J.M.; Pérez-Sánchez, H. Effect of inclusion of hydroxycinnamic and chlorogenic acids from green coffee bean in $\beta$-cyclodextrin on their interactions with whey, egg white and soy protein isolates. Food Chem. 2015, 168, 276-287. [CrossRef]

97. Rawel, H.M.; Czajka, D.; Rohn, S.; Kroll, J. Interactions of different phenolic acids and flavonoids with soy proteins. Int. J. Biol Macromol. 2002, 30, 137-150. [CrossRef]

98. Monteiro, M.C.; Marques, V.; Farah, A. Chlorogenic acids from green and roasted coffees are equally absorbed and metabolized by humans. FASEB J. 2010, 24, 922.

99. Marques, V.X.; Farah, A. Urinary excretion of chlorogenic acids and metabolites in humans after green mate (I. paraguariensis) consumption. FASEB J. 2010, 24, 922.

100. Bravo, X. Polyphenols: Chemistry, dietary sources, metabolism, and nutritional significance. Nutr. Rev. 1998, 56, 317-333. [CrossRef]

101. Gutnisky, A.; Rizzo, N.; Castro, M.E.; Garbossa, G. The inhibitory action of chlorogenic acid on the intestinal iron absorption in rats. Acta Physiol. Pharmacol. Ther. Latinoam. 1992, 42, 139-146.

102. Brune, M.; Rossander, L.; Hallberg, L. Iron absorption and phenolic compounds: Importance of different phenolic structures. Eur. J. Clin. Nutr. 1989, 43, 547-557. [PubMed]

103. Matsui, Y.; Shibata, H. Iron chelation by chlorogenic acid as a natural antioxidant. Biosci. Biotechnol. Biochem. 1998, 62, 22-27. [CrossRef]

104. Freedman, N.; Park, Y.; Abnet, C.C.; Hollenbeck, A.R.; Sinha, R. Association of coffee drinking with total and cause-specific mortality. N. Engl. J. Med. 2012, 366, 1891-1894. [CrossRef] 
105. Liu, J.; Sui, X.; Lavie, C.J.; Hebert, J.R.; Earnest, C.P.; Zhang, J.; Blair, S.N. Association of coffee consumption with all-cause and cardiovascular disease mortality. Mayo Clin. Proc. 2013, 88, 1066-1074. [CrossRef] [PubMed]

106. Crippa, A.; Discacciati, A.; Larsson, S.C.; Wolk, A.; Orsini, N. Coffee consumption and mortality from all causes, cardiovascular disease, and cancer: A dose-response meta-analysis. Am. J. Epidemiol. 2014, 180, 763-765. [CrossRef]

107. Loftfield, E.; Freedman, N.D.; Graubard, B.I.; Guertin, K.A.; Black, A.; Huang, W.-Y.; Shebl, F.M.; Mayne, S.T.; Sinha, R. Association of coffee consumption with overall and cause-specific mortality in a large US prospective cohort study. Am. J. Epidemiol. 2015, 182, 1010-1022. [CrossRef] [PubMed]

108. Ding, M.; Satija, A.; Bhupathiraju, S.N.; Hu, Y.; Sun, Q.; Han, J.; Lopez-Garcia, E.; Willet, W.; van Dam, R.M.; $\mathrm{Hu}$, F.A. Association of coffee consumption with total and cause-specific mortality in 3 large prospective cohorts. Circulation 2015, 132, 2305-2315. [CrossRef]

109. USDA National Nutrient Database for Standard Reference (Release 28, Released September 2015, Slightly Revised May 2016) United States Department of Agriculture. Available online: https:/ /ndb.nal.usda.gov/ ndb (accessed on 18 November 2018).

110. Farah, A.; Donangelo, C.M. Phenolic compounds in coffee. Braz. J. Plant Physiol. 2006, 18, 23-36. [CrossRef]

111. Liang, N.; Kitts, D.D. Role of chlorogenic acids in controlling oxidative and inflammatory stress conditions. Nutrients 2016, 8, 16. [CrossRef] [PubMed]

112. Tajik, N.; Tajik, M.; Mack, I.; Enk, P. The potential effects of chlorogenic acid, the main phenolic components in coffee, on health: A comprehensive review of the literature. Eur. J. Nutr. 2017, 56, 2215-2244. [CrossRef] [PubMed]

113. Naveed, M.; Hejazic, V.; Abbasa, M.; Kambohd, A.A.; Khane, G.J.; Shumzaidf, M.; Ahmadg, F.; Babazadehh, D.; FangFangi, X.; Modarresi-Ghazanij, F.; et al. Chlorogenic acid (CGA): A pharmacological review and call for further research. Biomed. Pharmacother. 2018, 97, 67-74. [CrossRef] [PubMed]

114. Li, S.; Bian, H.; Liu, Z.; Wang, Y.; Dai, J.; He, W.; Liao, X.; Liu, R.; Luo, J. Chlorogenic acid protects MSCs against oxidative stress by altering FOXO family genes and activating intrinsic pathway. Eur. J. Pharmacol. 2012, 674, 65-72. [CrossRef] [PubMed]

115. Han, D.; Chen, W.; Gu, X.; Shan, R.; Zou, J.; Liu, G.; Shahid, M.; Gao, J.; Han, B. Cytoprotective effect of chlorogenic acid against hydrogen peroxide-induced oxidative stress in MC3T3-E1 cells through $\mathrm{PI} 3 \mathrm{~K} /$ Akt-mediated Nrf2/HO-1 signaling pathway. Oncotarget 2017, 8, 14680-14692. [CrossRef] [PubMed]

116. Khansari, N.; Shakiba, Y.; Mahmoudi, M. Chronic inflammation and oxidative stress as a major cause of age-related diseases and cancer. Recent Pat. Inflamm. Allergy Drug Discov. 2009, 3, 73-80. [CrossRef]

117. Akash, M.S.H.; Rehman, K.; Chen, S. Effects of coffee on type 2 diabetes mellitus. Nutrition 2014, 30, 755-763. [CrossRef] [PubMed]

118. Nakatani, N.; Kayano, S.; Kikuzaki, H.; Sumino, K.; Katagiri, K.; Mitani, T. Identification, quantitative determination, and antioxidative activities of chlorogenic acid isomers in prune (Prunus domestica L.). J. Agric. Food Chem. 2000, 48, 5512-5516. [CrossRef]

119. Upadhyay, R.; Mohan Rao, L.J. An outlook on chlorogenic acids-occurrence, chemistry, technology, and biological activities. Crit. Rev. Food Sci. Nutr. 2013, 53, 968-984. [CrossRef]

120. Laranjinha, J.A.N.; Almeida, L.M.; Madeira, V.C.M. Reactivity of dietary phenolic acids with peroxyl radicals: Antioxidant activity upon low density lipoprotein peroxidation. Biochem. Pharmacol. 1994, 48, 487-494. [CrossRef]

121. Gordon, M.H.; Wishart, K.J. Effects of chlorogenic acid and bovine serum albumin on the oxidative stability of low-density lipoproteins in vitro. J. Agric. Food Chem. 2010, 58, 5828-5833. [CrossRef] [PubMed]

122. Cinkilic, N.; Cetintas, S.K.; Zorlu, T.; Vatan, O.; Yilmaz, D.; Cavas, T.; Tunc, S.; Ozkan, L.; Bilaloglu, R. Radioprotection by two phenolic compounds: Chlorogenic and quinic acid, on X-ray induced DNA damage in human blood lymphocytes in vitro. Food Chem. Toxicol. 2013, 53, 359-363. [CrossRef] [PubMed]

123. Zang, L.Y.; Cosma, G.; Gardner, H.; Vallyathan, V.; Castranova, V. Effect of chlorogenic acid on hydroxyl radical. Mol. Cell. Biochem. 2003, 247, 205-2010. [CrossRef] [PubMed]

124. Cha, J.W.; Piao, M.J.; Kim, K.C.; Yao, C.W.; Zheng, J.; Kim, S.M.; Hyun, C.L.; Ahn, Y.S.; Hyun, J.W. The polyphenol chlorogenic acid attenuates UVB-mediated oxidative stress in human HaCaT keratinocytes. Biomol. Ther. 2014, 22, 136-142. [CrossRef] [PubMed] 
125. Kono, Y.; Kobayashi, K.; Tagawa, S.; Adachi, K.; Ueda, A.; Sawa, Y.; Shibata, H. Antioxidant activity of polyphenolics in diets. Rate constants of reactions of chlorogenic acid and caffeic acid with reactive species of oxygen and nitrogen. BBA Gen. Subj. 1997, 1335, 335-342. [CrossRef]

126. Xu, J.G.; Hu, Q.P.; Liu, Y.J. Antioxidant and DNA-protective activities of chlorogenic acid isomers. J. Agric. Food Chem. 2012, 60, 11625-11630. [CrossRef] [PubMed]

127. Khan, F.; Maalik, A.; Murtaza, G. Inhibitory mechanism against oxidative stress of caffeic acid. J. Food Drug Anal. 2016, 24, 695-702. [CrossRef] [PubMed]

128. Marković, S.; Tošović, J. Comparative study of the antioxidative activities of caffeoylquinic and caffeic acids. Food Chem. 2016, 210, 585-592. [CrossRef] [PubMed]

129. Kim, J.; Lee, S.; Shim, J.; Kim, H.W.; Kim, J.; Jang, Y.J.; Yang, H.; Park, J.; Choi, S.H.; Yoon, J.H.; et al. Caffeinated coffee, decaffeinated coffee, and the phenolic phytochemical chlorogenic acid up-regulate NQO1 expression and prevent $\mathrm{H}_{2} \mathrm{O}_{2}$-induced apoptosis in primary cortical neurons. Neurochem. Int. 2012, 60, 466-474. [CrossRef] [PubMed]

130. Park, J.B. Isolation and quantification of major chlorogenic acids in three major instant coffee brands and their potential effects on $\mathrm{H}_{2} \mathrm{O}_{2}$-induced mitochondrial membrane depolarization and apoptosis in PC-12 cells. Food Funct. 2013, 4, 1632-1638. [CrossRef] [PubMed]

131. Baeza, G.; Amigo-Benavent, M.; Sarria, B.; Goya, L.; Mateos, R.; Bravo, L. Green coffee hydroxycinnamic acids but not caffeine protect human HepG2 cells against oxidative stress. Food. Res. Int. 2014, 62, 1038-1046. [CrossRef]

132. Karthikesan, K.; Pari, L.; Menon, V.P. Protective effect of tetrahydrocurcumin and chlorogenic acid against streptozotocin-nicotinamide generated oxidative stress induced diabetes. J. Funct. Foods 2010, 2, 134-142. [CrossRef]

133. Pari, L.; Karthikesan, K.; Menon, V.P. Comparative and combined effect of chlorogenic acid and tetrahydrocurcumin on antioxidant disparities in chemical induced experimental diabetes. Mol. Cell. Biochem. 2010, 341, 109-117. [CrossRef] [PubMed]

134. Koriem, K.M.M.; Soliman, R.E. Chlorogenic and caftaric acids in liver toxicity and oxidative stress induced by methamphetamine. J. Toxicol. 2014. [CrossRef] [PubMed]

135. Biswas, S.K. Does the interdependence between oxidative stress and inflammation explain the antioxidant paradox? Oxid. Med. Cell. Longev. 2016. [CrossRef] [PubMed]

136. Cachofeiro, V.; Goicochea, M.; Garcia de Vinuesa, S.; Oubina, P.; Lahera, V.; Luño, J. Oxidative stress and inflammation, a link between chronic kidney disease and cardiovascular disease. Kidney Int. 2008, 74, 4-9. [CrossRef] [PubMed]

137. Ambade, A.; Mandrekar, P. Oxidative stress and inflammation: Essential partners in alcoholic liver disease. Int. J. Hepatol. 2012. [CrossRef]

138. Biswas, S.K.; Lopes de Faria, J.B. Which comes first: Renal inflammation or oxidative stress in spontaneously hypertensive rats? Free Radic. Res. 2007, 41, 216-224. [CrossRef]

139. Cotran, R.S.; Kumar, V.; Robbins, S.L.; Schoen, F.J. Cellular injury and cellular death. In Robbins Pathologic Basis of Disease; WB Saunders Company: Philadelphia, PA, USA, 1994; pp. 1-34. ISBN 978-1455726134.

140. Shin, H.S.; Satsu, H.; Bae, M.J.; Zhao, Z.H.; Ogiwara, H.; Totsuka, M.; Shimizu, M. Anti-inflammatory effect of chlorogenic acid on the IL-8 production in Caco-2 cells and the dextran sulphate sodium-induced colitis symptoms in C57BL/ 6 mice. Food Chem. 2015, 168, 167-175. [CrossRef]

141. Shan, J.; Fu, J.; Zhao, Z.; Kong, X.; Huang, H.; Luo, L.; Yin, Z. Chlorogenic acid inhibits lipopolysaccharide-induced cyclooxygenase-2 expression in RAW264.7 cells through suppressing NF-kappaB and JNK/AP-1 activation. Int. Immunopharmacol. 2009, 9, 1042-1048. [CrossRef] [PubMed]

142. Zatorski, H.; Sałaga, M.; Zielin'ska, M.; Piechota-Polan'czyk, A.; Owczarek, K.; Kordek, R.; Lewandowska, U.; Chen, C.; Fichna, J. Experimental colitis in mice is attenuated by topical administration of chlorogenic acid. Naunyn-Schmiedeberg's Arch. Pharmacol. 2015, 388, 643-651. [CrossRef] [PubMed]

143. Bagdas, D.; Gul, N.Y.; Topal, A. Pharmacologic overview of systemic chlorogenic acid therapy on experimental wound healing. Naunyn-Schmiedeberg's Arch. Pharmacol. 2014, 387, 1101-1116. [CrossRef] [PubMed]

144. Bagdas, D.; Etoz, B.C.; Gul, Z.; Ziyanok, S.; Inan, S.; Turacozen, O.; Gul, N.Y.; Topal, A.; Cinkilic, N.; Tas, S.; et al. In vivo systemic chlorogenic acid therapy under diabetic conditions: Wound healing effects and cytotoxicity/genotoxicity profile. Food Chem. Toxicol. 2015, 81, 54-61. [CrossRef] [PubMed] 
145. Affonso, R.C.L.; Voytena, A.P.L.; Fanan, S.; Pitz, H.; Coelho, D.S.; Horstmann, A.L.; Pereira, A.; Uarrota, V.G.; Hillmann, M.C.; Varela, L.A.C.; et al. Phytochemical composition, antioxidant activity, and the effect of the aqueous extract of coffee (Coffea arabica L.) bean residual press cake on the skin wound healing. Oxid. Med. Cell. Longev. 2016. [CrossRef] [PubMed]

146. Toyokuni, S. Oxidative stress as an iceberg in carcinogenesis and cancer biology. Arch. Biochem. Biophys. 2016, 595, 46-49. [CrossRef] [PubMed]

147. Ramos, S. Cancer chemoprevention and chemotherapy: Dietary polyphenols and signalling pathways. Mol. Nutr. Food Res. 2008, 52, 507-526. [CrossRef] [PubMed]

148. Nkondjock, A. Coffee consumption and the risk of cancer: An overview. Cancer Lett. 2009, 277, 121-125. [CrossRef] [PubMed]

149. Ya-Min, L.; Peng, J.; Le-Zhi, L. Coffee consumption associated with reduced risk of oral cancer: A metaanalysis. Oral Surg. Oral Med. Oral Pathol. Oral Radiol. 2016, 121, 381-389. [CrossRef]

150. Mishra, M.; Panta, R.; Miyares, M. Influence of coffee and its components on breast cancer: A review. Asian Pac. J. Trop. Dis. 2016, 6, 827-831. [CrossRef]

151. Mori, H.; Tanaka, T.; Shima, H.; Kuniyasu, T.; Takahashi, M. Inhibitory effect of chlorogenic acid on methylazoxymethanol acetate-induced carcinogenesis in large intestine and liver of hamsters. Cancer Lett. 1986, 30, 49-54. [CrossRef]

152. Feng, R.; Lu, Y.; Bowman, L.L.; Qian, Y.; Castranova, V.; Ding, M. Inhibition of activator protein-1, NF-kappaB, and MAPKs and induction of phase 2 detoxifying enzyme activity by chlorogenic acid. J. Biol. Chem. 2005, 280, 27888-27895. [CrossRef] [PubMed]

153. Jurkowska, R.Z.; Jurkowski, T.P.; Jeltsch, A. Structure and function of mammalian DNA methyltransferases. Eur. J. Chem. Biol. 2011, 12, 206-222. [CrossRef]

154. Kasai, H.; Fukada, S.; Yamaizumi, Z.; Sugie, S.; Mori, H. Action of chlorogenic acid in vegetables and fruits as an inhibitor of 8-hydroxydeoxyguanosine formation in vitro and in a rat carcinogenesis model. Food Chem. Toxicol. 2000, 38, 467-471. [CrossRef]

155. Ludwig, I.A.; Clifford, M.N.; Lean, M.E.J.; Ashihara, H.; Crozier, A. Coffee: Biochemistry and potential impact on health. Food Funct. 2014, 5, 1695-1717. [CrossRef] [PubMed]

156. Boettler, U.; Volz, N.; Pahlke, G.; Teller, N.; Kotyczka, C.; Somoza, V.; Stiebitz, H.; Bytof, G.; Lantz, I.; Lang, R. Coffees rich in chlorogenic acid or N-methylpyridinium induce chemopreventive phase II-enzymes via the Nrf2/ARE pathway in vitro and in vivo. Mol. Nutr. Food Res. 2011, 55, 798-802. [CrossRef] [PubMed]

157. Honjo, S.; Kono, S.; Coleman, M.P.; Shinchi, K.; Sakurai, Y.; Todoroki, I.; Umeda, T.; Wakabayashi, K.; Imanishi, K.; Nishikawa, H. Coffee consumption and serum aminotransferases in middle-aged Japanese men. J. Clin. Epidemiol. 2001, 54, 823-829. [CrossRef]

158. La Vecchia, C. Coffee, liver enzymes, cirrhosis and liver cancer. J. Hepatol. 2005, 42, 444-446. [CrossRef]

159. Wadhawan, M.; Anand, A.C. Coffee and Liver Disease. J. Clin. Exp. Hepatol. 2016, 6, 40-46. [CrossRef]

160. Wang, G.F.; Shi, L.P.; Ren, Y.D.; Liu, Q.F.; Liu, H.F.; Zhang, R.J.; Li, Z.; Zhu, F.H.; He, P.L.; Tang, W. Anti-hepatitis B virus activity of chlorogenic acid, quinic acid and caffeic acid in vivo and in vitro. Antivir. Res. 2009, 83, 186-190. [CrossRef]

161. Larsson, C.; Wolk, A. Coffee consumption and risk of liver cancer: A meta-analysis. Gastroenterology 2007, 132, 1740-1745. [CrossRef] [PubMed]

162. Bravi, F.; Bosetti, C.; Tavoni, A.; Gallus, S.; La Vecchia, C. Coffee reduces risk for hepatocellular carcinoma: An updated meta-analysis. Clin. Gastroenterol. Hepatol. 2013, 11, 1413-1421. [CrossRef] [PubMed]

163. Ji, L.; Jiang, P.; Lu, B.; Sheng, Y.; Wang, X.; Wang, Z. Chlorogenic acid, a dietary polyphenol, protects acetaminophen-induced liver injury and its mechanism. J. Nutr. Biochem. 2013, 24, 1911-1929. [CrossRef] [PubMed]

164. Yun, N.; Kang, J.W.; Lee, S.M. Protective effects of chlorogenic acid against ischemia/reperfusion injury in rat liver: Molecular evidence of its antioxidant and anti-inflammatory properties. J. Nutr. Biochem. 2012, 23, 1249-1255. [CrossRef] [PubMed]

165. Shi, H.; Shi, A.; Dong, L.; Lu, X.; Wang, Y.; Zhao, J.; Dai, F.; Guo, X. Chlorogenic acid protects against liver fibrosis in vivo and in vitro through inhibition of oxidative stress. Clin. Nutr. 2016, 35, 1366-1373. [CrossRef] [PubMed] 
166. Machado, S.R.; Parise, E.R.; Carvalho, L. Coffee has hepatoprotective benefits in Brazilian patients with chronic hepatitis $C$ even in lower daily consumption than in American and European populations. Braz. J. Infect. Dis. 2014, 18, 170-176. [CrossRef] [PubMed]

167. Basnet, P.; Matsushige, K.; Hase, K.; Kadota, S.; Namba, T. Four di-O-caffeoyl quinic acid derivatives from propolis. Potent hepatoprotective activity in experimental liver injury models. Biol. Pharm. Bull. 1996, 19, 1479-1484. [CrossRef]

168. Xu, Y.; Chen, J.; Yu, X.; Tao, W.; Jiang, F.; Yin, Z.; Liu, C. Protective effects of chlorogenic acid on acute hepatotoxicity induced by lipopolysaccharide in mice. Inflamm. Res. 2010, 59, 871-877. [CrossRef]

169. Shi, H.; Dong, L.; Bai, Y.; Zhao, J.; Zhang, Y.; Zhang, L. Chlorogenic acid against carbon tetrachloride-induced liver fibrosis in rats. Eur. J. Pharmacol. 2009, 623, 119-124. [CrossRef]

170. Shi, H.; Dong, L.; Jiang, J.; Zhao, J.; Zhao, G.; Dang, X.; Lu, X.; Jia, M. Chlorogenic acid reduces liver inflammation and fibrosis through inhibition of toll-like receptor 4 signaling pathway. Toxicology 2013, 303, 107-114. [CrossRef]

171. Zhang, W.; Lopez-Garcia, E.; Li, T.Y.; Hu, F.B.; van Dam, R.M. Coffee consumption and risk of cardiovascular diseases and all-cause mortality among men with type 2 diabetes. Diabetes Care 2009, 32, 1043-1045. [CrossRef] [PubMed]

172. Lin, W.Y.; Pi-Sunyer, F.X.; Chen, C.C.; Davidson, L.E.; Liu, C.S.; Li, T.C.; Wu, M.F.; Li, C.I.; Chen, W.; Lin, C.C. Coffee consumption is inversely associated with type 2 diabetes in Chinese. Eur. J. Clin. Investig. 2011, 41, 659-666. [CrossRef] [PubMed]

173. Bakuradze, T.; Boehm, N.; Janzowski, C.; Lang, R.; Hofmann, T.; Stockis, J.-P.; Albert, F.W.; Stiebitz, H.; Bytof, G.; Lantz, I.; et al. Antioxidant-rich coffee reduces DNA damage, elevates glutathione status and contributes to weight control: Results from an intervention study. Mol. Nutr. Food Res. 2011, 55, 793-797. [CrossRef] [PubMed]

174. Huxley, R.; Lee, C.M.Y.; Barzi, F.; Timmermeister, L.; Czernichow, S.; Perkovic, V.; Grobbee, D.E.; Batty, D.; Woodward, M. Coffee, decaffeinated coffee, and tea consumption in relation to incident type 2 diabetes mellitus: A systematic review with meta-analysis. Arch. Intern. Med. 2009, 169, 2053-2063. [CrossRef] [PubMed]

175. Kempf, K.; Herder, C.; Erlund, I.; Kolb, H.; Martin, S.; Carstensen, M.; Koenig, W.; Sandwall, J.; Bidel, S.; Kuha, S.; et al. Effects of coffee consumption on subclinical inflammation and other risk factors for type 2 diabetes: A clinical trial. Am. J. Clin. Nutr. 2010, 91, 950-957. [CrossRef] [PubMed]

176. van Dijk, A.E.; Olthof, M.R.; Meeuse, J.C.; Seebus, E.; Heine, R.J.; van Dam, R.M. Acute effects of decaffeinated coffee and the major coffee components chlorogenic acid and trigonelline on glucose tolerance. Diabetes Care 2009, 32, 1023-1025. [CrossRef] [PubMed]

177. Rios, J.L.; Francini, F.; Schinella, G.R. Natural Products for the Treatment of Type 2 Diabetes Mellitus. Planta Med. 2015, 81, 975-994. [CrossRef]

178. Shearer, J.; Sellars, E.; Farah, A.; Graham, T.E.; Wasserman, D.H. Effects of chronic coffee consumption on glucose kinetics in the conscious rat. Can. J. Physiol. Pharmacol. 2007, 85, 823-830. [CrossRef]

179. Shin, J.Y.; Sohn, J.; Park, K.H. Chlorogenic acid decreases retinal vascular hyperpermeability in diabetic rat model. J. Korean Med. Sci. 2013, 28, 608-613. [CrossRef]

180. Lecoultre, V.; Carrel, G.; Egli, L.; Binnert, C.; Boss, A.; MacMillan, E.L.; Kreis, R.; Boesch, C.; Darimont, C.; Tappy, L. Coffee consumption attenuates short-term fructose-induced liver insulin resistance in healthy men. Am. J. Clin. Nutr. 2014, 99, 268-275. [CrossRef]

181. Simon, C.; Herling, A.W.; Preibisch, G.; Burger, H.J. Upregulation of hepatic glucose 6-phosphatase gene expression in rats treated with an inhibitor of glucose-6-phosphate translocase. Arch. Biochem. Biophys. 2000, 373, 418-428. [CrossRef] [PubMed]

182. Waite, M. Treatment for Alzheimer's disease: Has anything changed? Austr. Prescr. 2015, 38, 60-63. [CrossRef]

183. Shearer, J.; Farah, A.; de Paulis, T.; Bracy, D.P.; Pencek, R.R.; Graham, T.E.; Wasserman, D.H. Quinides of roasted coffee enhance insulin action in conscious rats. J. Nutr. 2003, 133, 3529-3532. [CrossRef] [PubMed]

184. World Health Organization-WHO. The Top 10 Causes of Death. Available online: http://www.who.int/ mediacentre/factsheets/fs310/en/ (accessed on 18 November 2018).

185. Taguchi, K.; Hida, M.; Matsumoto, T.; Ikeuchi-Takahashi, Y.; Onishi, H.; Kobayashi, T. Effect of short-term polyphenol treatment on endothelial dysfunction and thromboxane A2 levels in streptozotocin-induced diabetic mice. Biol. Pharm. Bull. 2014, 37, 1056-1061. [CrossRef] [PubMed] 
186. McDowell, I.F.; Lang, D. Homocysteine and endothelial dysfunction: A link with cardiovascular disease. J. Nutr. 2000, 130, 369-372. [CrossRef] [PubMed]

187. Park, J.B. 5-Caffeoylquinic acid and caffeic acid orally administered suppress P-selectin expression on mouse platelets. J. Nutr. Biochem. 2009, 20, 800-805. [CrossRef]

188. Sato, Y.; Itagaki, S.; Kurokawa, T.; Ogura, J.; Kobayashi, M.; Hirano, T.; Sugawara, M.; Iseki, K. In vitro and in vivo antioxidant properties of chlorogenic acid and caffeic acid. Int. J. Pharm. 2011, 403, 136-138. [CrossRef] [PubMed]

189. Kanegae, M.P.; da Fonseca, L.M.; Brunetti, L.L.; Silva, S.O.; Ximenes, V.F. The reactivity of ortho-methoxysubstituted catechol radicals with sulfhydryl groups: Contribution for the comprehension of the mechanism of inhibition of NADPH oxidase by apocynin. Biochem. Pharmacol. 2007, 74, 457-464. [CrossRef]

190. Furukawa, S.; Fujita, T.; Shimabukuro, M.; Iwaki, M.; Yamada, Y.; Nakajima, Y.; Nakayama, O.; Makishima, M.; Matsuda, M.; Shimomura, I. Increased oxidative stress in obesity and its impact on metabolic syndrome. J. Clin. Investig. 2004, 114, 1752-1761. [CrossRef] [PubMed]

191. Santana-Gálvez, J.; Cisneros-Zevallos, L.; Jacobo-Velázquez, D.A. Chlorogenic acid: Recent advances on its dual role as a food additive and a nutraceutical against metabolic syndrome. Molecules 2017, 22, 358. [CrossRef] [PubMed]

192. Kaur, J. A comprehensive review on metabolic syndrome. Cardiol. Res. Pract. 2014. [CrossRef] [PubMed]

193. Monteiro, R.; Azevedo, I. Chronic Inflammation in Obesity and the Metabolic Syndrome. Mediat. Inflamm. 2010, 289645. [CrossRef] [PubMed]

194. Hino, A.; Adachi, H.; Enomoto, M.; Furuki, K.; Shigetoh, Y.; Ohtsuka, M.; Kumagae, S.; Hirai, Y.; Jalaldin, A.; Satoh, A.; et al. Habitual coffee but not green tea consumption is inversely associated with metabolic syndrome: An epidemiological study in a general Japanese population. Diabetes Res. Clin. Pract. 2007, 76, 383-389. [CrossRef] [PubMed]

195. Mure, K.; Maeda, S.; Mukoubayashi, C.; Mugitani, K.; Iwane, M.; Kinoshita, F.; Mohara, O.; Takeshita, T. Habitual coffee consumption inversely associated with metabolic syndrome-related biomarkers involving adiponectin. Nutrition 2013, 29, 982-987. [CrossRef] [PubMed]

196. Lopez-Garcia, E.; van Dam, R.M.; Rajpathak, S.; Willett, W.C.; Manson, J.E.; Hu, F.B. Changes in caffeine intake and long-term weight change in men and women. Am. J. Clin. Nutr. 2006, 83, 674-680. [CrossRef] [PubMed]

197. Greenberg, J.; Axen, K.; Schnoll, R.; Boozer, C. Coffee, tea and diabetes: The role of weight loss and caffeine. Int. J. Obes. 2005, 29, 1121-1129. [CrossRef] [PubMed]

198. Thom, E. The effect of chlorogenic acid enriched coffee on glucose absorption in healthy volunteers and its effect on body mass when used long-term in overweight and obese people. J. Int. Med. Res. 2007, 35, 900-908. [CrossRef] [PubMed]

199. Ma, Y.; Gao, M.; Liu, D. Chlorogenic acid improves high fat diet-induced hepatic steatosis and insulin resistance in mice. Pharm. Res. 2015, 32, 1200-1209. [CrossRef]

200. Cho, A.S.; Jeon, S.M.; Kim, M.J.; Yeo, J.; Seo, K.I.; Choi, M.S.; Lee, M.K. Chlorogenic acid exhibits anti-obesity property and improves lipid metabolism in high-fat diet-induced-obese mice. Food Chem. Toxicol. 2010, 48, 937-943. [CrossRef]

201. Meng, S.; Cao, J.; Feng, Q.; Peng, J.; Hu, Y. Roles of Chlorogenic Acid on Regulating Glucose and Lipids Metabolism: A Review. Evid. Based Complement. Alternat. Med. 2013. [CrossRef]

202. de Sotillo, D.V.R.; Hadley, M.; Sotillo, J.E. Insulin receptor exon 11+/- is expressed in Zucker (fa/fa) rats, and chlorogenic acid modifies their plasma insulin and liver protein and DNA. J. Nutr. Biochem. 2006, 17, 63-71. [CrossRef] [PubMed]

203. Shimoda, H.; Seki, E.; Aitani, M. Inhibitory effect of green coffee bean extract on fat accumulation and body weight gain in mice. BMC Complement. Altern. Med. 2006. [CrossRef] [PubMed]

204. Flanagan, J.; Bily, A.; Rolland, Y.; Roller, M. Lipolytic activity of Svetol®, a decaffeinated green coffee bean extract. Phytother. Res. 2014, 28, 946-948. [CrossRef] [PubMed]

205. Huang, K.; Liang, X.C.; Zhong, Y.L.; He, W.Y.; Wang, Z. 5-Caffeoylquinic acid decreases diet-induced obesity in rats by modulating PPAR $\alpha$ and LXR $\alpha$ transcription. J. Sci. Food Agric. 2015, 95, 1903-1910. [CrossRef] [PubMed]

206. Rosso, A.; Mossey, J.; Lippa, C.F. Caffeine: Neuroprotective functions in cognition and Alzheimer's disease. Am. J. Alzheimer's Dis. Other Demen. 2008, 23, 417-422. [CrossRef] [PubMed] 
207. Arendash, G.W.; Cao, C. Caffeine and Coffee as Therapeutics against Alzheimer's Disease. J. Alzheimer's Dis. 2010, 20, 117-126. [CrossRef] [PubMed]

208. Oboh, G.; Agunloye, O.M.; Akinyemi, A.J.; Ademiluyi, A.O.; Adefegha, S.A. Comparative study on the inhibitory effect of caffeic and chlorogenic acids on key enzymes linked to alzheimer's disease and some pro-oxidant induced oxidative stress in rats' brain-in vitro. Neurochem. Res. 2013, 38, 413-419. [CrossRef]

209. Pathak, L.; Agrawal, Y.; Dhir, A. Natural polyphenols in the management of major depression. Expert Opin. Investig. Drugs 2013, 22, 863-880. [CrossRef]

210. Esposito, E.; Rotilio, D.; Di Matteo, V.; Di Giulio, C.; Cacchio, M.; Algeri, S. A review of specific dietary antioxidants and the effects on biochemical mechanisms related to neurodegenerative processes. Neurobiol. Aging 2002, 23, 719-735. [CrossRef]

211. Ramassamy, C. Emerging role of polyphenolic compounds in the treatment of neurodegenerative diseases: A review of their intracellular targets. Eur. J. Pharmacol. 2006, 545, 51-64. [CrossRef]

212. Lakey-Beitia, J.; Berrocal, R.; Rao, K.S.; Durant, A.A. Polyphenols as therapeutic molecules in Alzheimer's disease through modulating amyloid pathways. Mol. Neurobiol. 2015, 51, 466-479. [CrossRef] [PubMed]

213. Shen, W.; Qi, R.; Zhang, J.; Wang, Z.; Wang, H.; Hu, C.; Zhao, Y.; Bie, M.; Wang, Y.; Fu, Y. Chlorogenic acid inhibits LPS-induced microglial activation and improves survival of dopaminergic neurons. Brain Res. Bull. 2012, 88, 487-494. [CrossRef] [PubMed]

214. Taram, F.; Winter, A.N.; Linseman, D.A. Neuroprotection comparison of chlorogenic acid and its metabolites against mechanistically distinct cell death-inducing agents in cultured cerebellar granule neurons. Brain Res. 2016, 1648, 69-80. [CrossRef] [PubMed]

215. Bouayed, J.; Rammal, H.; Dicko, A. Chlorogenic acid, a polyphenol from Prunus domestica (Mirabelle), with coupled anxiolytic and antioxidant effects. J. Neurol. Sci. 2007, 262, 77-84. [CrossRef] [PubMed]

216. Hall, S.; Desbrow, B.; Anoopkumar-Dukie, S.; Davey, A.K.; Arora, D.; McDermott, C.; Schubert, M.M.; Perkins, A.V.; Kiefel, M.J.; Grant, G.D. A review of the bioactivity of coffee, caffeine and key coffee constituents on inflammatory responses linked to depression. Food Res. Int. 2015, 76, 626-636. [CrossRef] [PubMed]

217. Chu, Y.F.; Brown, P.H.; Lyle, B.J.; Chen, Y.; Richard, B.M.; Williams, C.E.; Lin, Y.C.; Hsu, C.W.; Cheng, I.H. Roasted coffees high in lipophilic antioxidants and chlorogenic acid lactones are more neuroprotective than green coffees. J. Agric. Food Chem. 2009, 57, 9801-9808. [CrossRef] [PubMed]

218. Antônio, A.G.; Moraes, R.S.; Perrone, D.; Maia, L.C.; Santos, K.R.N.; Iorio, N.L.P.; Farah, A. Species, roasting degree and decaffeination influence the antibacterial activity of coffee against Streptococcus mutans. Food Chem. 2010, 118, 782-788. [CrossRef]

219. Almeida, A.A.P.; Naghetini, C.C.; Santos, V.R.; Antonio, A.G.; Farah, A.; Gloria, M.B.A. Influence of natural coffee compounds, coffee extracts and increased levels of caffeine on the inhibition of Streptococcus mutans. Food Res. Int. 2012, 49, 459-461. [CrossRef]

220. Karunanidhi, A.; Thomas, R.; Van Belkum, A.; Neela, V. In vitro antibacterial and antibiofilm activities of chlorogenic acid against clinical isolates of Stenotrophomonas maltophilia including the trimethoprim/sulfamethoxazole resistant strain. BioMed Res. Int. 2013. [CrossRef] [PubMed]

221. Farzaei, M.H.; Abdollahi, M.; Rahimi, R. Role of dietary polyphenols in the management of peptic ulcer. World J. Gastroenterol. 2015, 21, 6499-6517. [CrossRef]

222. Fu, L.; Lu, W.; Zhou, X. Phenolic compounds and in vitro antibacterial and antioxidant activities of three tropic fruits: Persimmon, guava, and sweetsop. BioMed Res. Int. 2016. [CrossRef] [PubMed]

223. Lou, Z.; Wang, H.; Zhu, S.; Ma, C.; Wang, Z. Antibacterial activity and mechanism of action of chlorogenic acid. J. Food Sci. 2011, 76, 398-403. [CrossRef] [PubMed]

224. Bajko, E.; Kalinowska, M.; Borowski, P.; Siergiejczyk, L.; Lewandowski, W. Uinic acid: A spectroscopic study and biological screening for antimicrobial activity. LWT-Food Sci. Technol. 2016, 65, 471-479. [CrossRef]

225. Kabir, F.; Katayama, S.; Tanji, N.; Nakamura, S. Antimicrobial effects of chlorogenic acid and related compounds. J. Korean Soc. Appl. Biol. Chem. 2014, 57, 359-365. [CrossRef]

226. Sales, A.; Miguel, M.A.L.; Farah, A. Effect of coffee aqueous extracts and bioactive compounds on probiotic bacteria growth. In Proceedings of the International Conference on Coffee Science (ASIC), Portland, OR, USA, 16-20 September 2018.

227. Sung, W.S.; Lee, D.G. Antifungal action of chlorogenic acid against pathogenic fungi, mediated by membrane disruption. Pure Appl. Chem. 2010, 82, 219-226. [CrossRef] 
228. Khan, M.T.H.; Ather, A.; Thompson, K.D.; Gambari, R. Extracts and molecules from medicinal plants against herpes simplex viruses. Antivir. Res. 2005, 67, 107-119. [CrossRef] [PubMed]

229. Tamura, H.; Akioka, T.; Ueno, K.; Chujyo, T.; Okazaki, K.I.; King, P.J.; Robinson, W.E. Anti-human immunodeficiency virus activity of 3,4,5-tricaffeoylquinic acid in cultured cells of lettuce leaves. Mol. Nutr. Food Res. 2006, 50, 396-400. [CrossRef]

230. Chiang, L.; Chiang, W.; Chang, M.Y.; Ng, L.T.; Lin, C. C Antiviral activity of Plantago major extracts and related compounds in vitro. Antivir. Res. 2002, 55, 53-62. [CrossRef]

231. Esposito, F.; Sanna, C.; Del Vecchio, C.; Cannas, V.; Venditti, A.; Corona, A.; Bianco, A.; Serrilli, A.M.; Guarcini, L.; Parolin, C. Hypericum hircinum L. components as new single-molecule inhibitors of both HIV-1 reverse transcriptase-associated DNA polymerase and ribonuclease H activities. Pathog. Dis. 2013, 68, 116-124. [CrossRef]

232. Pleško, S.; Volk, H.; Lukšič, M.; Podlipnik, Č. In silico study of plant polyphenols' interactions with VP24-Ebola virus membrane-associated protein. Acta Chim. Slov. 2015, 62, 555-564. [CrossRef]

233. Allsopp, P.; Possemiers, S.; Campbell, D.; Ovarzábal, I.S.; Gill, C.; Rowland, I. An exploratory study into the putative prebiotic activity of fructans isolated from Agave angustifolia and the associated anticancer activity. Anaerobe 2013, 22, 38-44. [CrossRef] [PubMed]

234. Saha, D.C.; Reimer, R.A. Long-term intake of a high prebiotic fiber diet but not high protein reduces metabolic risk after a high fat challenge and uniquely alters gut microbiota and hepatic gene expression. Nutr. Res. 2014, 34, 789-796. [CrossRef] [PubMed]

235. Kelly-Quagliana, K.A.; Nelson, P.D.; Buddington, R.K. Dietary oligofructose and inulin modulate immune functions in mice. Nutr. Res. 2003, 23, 257-267. [CrossRef]

236. Kumar, V.P.; Prashanth, K.V.H.; Venkatesh, Y.P. Structural analyses and immunomodulatory properties of fructo-oligosaccharides from onion (Allium cepa). Carbohydr. Polym. 2015, 117, 115-122. [CrossRef]

237. Munjal, U.; Glei, M.; Pool-Zobel, B.L.; Scharlau, D. Fermentation products of inulin-type fructans reduce proliferation and induce apoptosis in human colon tumour cells of different stages of carcinogenesis. Br. J. Nutr. 2009, 102, 663-671. [CrossRef] [PubMed]

238. Griffin, I.J.; Hicks, P.M.D.; Heaney, R.P.; Abrams, S.A. Enriched chicory inulin increases calcium absorption mainly in girls with lower calcium absorption. Nutr. Res. 2003, 23, 901-909. [CrossRef]

239. Fernandes, R.; Beserra, B.T.S.; Mocellin, M.C.; Kuntz, M.G.F.; da Rosa, J.S.; de Miranda, R.C.D.; Schreiber, C.S.O.; Fröde, T.S.; Nunes, E.A.; Trindade, E.B.S.M. Effects of prebiotic and synbiotic supplementation on inflammatory markers and anthropometric indices after roux-en-Y gastric bypass: A randomized, triple-blind, placebo-controlled pilot study. J. Clin. Gastroenterol. 2015, 50, 208-217. [CrossRef]

240. Cluny, N.L.; Eller, L.K.; Keenan, C.M.; Reimer, R.A.; Sharkey, K.A. Interactive effects of oligofructose and obesity predisposition on gut hormones and microbiota in diet-induced obese rats. Obesity 2015, 23, 769-778. [CrossRef] [PubMed]

241. Abrams, S.A.; Griffin, I.J.; Hawthorne, K.M.; Ellis, K.J. Effect of prebiotic supplementation and calcium intake on body mass index. J. Pediatr. 2007, 151, 293-298. [CrossRef]

242. Delzenne, N.M.; Cani, P.D.; Everard, A.; Neyrinck, A.M.; Bindels, L.B. Gut microorganisms as promising targets for the management of type 2 diabetes. Diabetologia 2015, 58, 2206-2217. [CrossRef]

243. Kellow, N.J.; Coughlan, M.T.; Savige, G.S.; Reid, C.M. Effect of dietary prebiotic supplementation on advanced glycation, insulin resistance and inflammatory biomarkers in adults with pre-diabetes: A study protocol for a double-blind placebo-controlled randomised crossover clinical trial. BMC Endocr. Disord. 2014, 14. [CrossRef] [PubMed]

244. Gonthier, M.P.; Remesy, C.; Scalbert, A.; Cheynier, V.; Souquet, J.M.; Poutanen, K.; Aura, A.M. Microbial metabolism of caffeic acid and its esters chlorogenic and caftaric acids by human faecal microbiota in vitro. Biomed. Pharmacother. 2006, 60, 536-540. [CrossRef] [PubMed]

245. Rechner, A.R.; Spencer, J.P.E.; Kuhnle, G.; Hahn, U.; Rice-Evans, C.A. Novel biomarkers of the metabolism of caffeic acid derivatives in vivo. Free Radic. Biol. Med. 2001, 30, 1213-1222. [CrossRef] 
246. Parkar, S.G.; Trower, T.M.; Stevenson, D.E. Fecal microbial metabolism of polyphenols and its effects on human gut microbiota. Anaerobe 2013, 23. [CrossRef] [PubMed]

247. Mills, C.E.; Tzounis, X.; Oruna-Concha, M.J.; Mottram, D.S.; Gibson, G.R.; Spencer, J.P.E. In vitro colonic metabolism of coffee and chlorogenic acid results in selective changes in human faecal microbiota growth. Br. J. Nutr. 2015, 113, 1220-1227. [CrossRef] [PubMed]

(c) 2019 by the authors. Licensee MDPI, Basel, Switzerland. This article is an open access article distributed under the terms and conditions of the Creative Commons Attribution (CC BY) license (http://creativecommons.org/licenses/by/4.0/). 